\title{
Efficacy of topical agents for prevention of postoperative sore throat after single lumen tracheal intubation: a Bayesian network meta-analysis
}

\section{Efficacité des agents topiques pour la prévention des maux de gorge postopératoires après une intubation avec tube endotrachéal simple lumière : une méta-analyse bayésienne en réseau}

\author{
Narinder P. Singh, MD • Jeetinder K. Makkar, MD $\mathbb{D} \cdot$ Ron B. Cappellani, FRCPC • \\ Ashish Sinha, MD • Anand Lakshminarasimhachar, MD • Preet Mohinder Singh, MD \\ Received: 16 July 2019/Revised: 7 May 2020/Accepted: 11 May 2020/Published online: 20 August 2020 \\ (c) Canadian Anesthesiologists' Society 2020
}

\begin{abstract}
Background The optimal choice of prophylactic drugs to decrease postoperative sore throat is unclear. The objective of this network meta-analysis (NMA) was to compare and rank 11 topical agents used to prevent postoperative sore throat.
\end{abstract}

Electronic supplementary material The online version of this article (https://doi.org/10.1007/s12630-020-01792-4) contains supplementary material, which is available to authorized users.

N. P. Singh, MD

Department of Anesthesia, Perioperative and Pain Medicine,

University of Manitoba, Winnipeg, MB, Canada

Present address

MMIMSR, MM (DU), Mullana-Ambala, India

J. K. Makkar, MD (ه)

Department of Anaesthesia and Intensive Care, Post Graduate Institute of Medical Education and Research, Sector 12,

Chandigarh 160012, India

e-mail: jeet1516@gmail.com

R. B. Cappellani, FRCPC

Department of Anesthesia, Perioperative and Pain Medicine,

University of Manitoba, Winnipeg, MB, Canada

A. Sinha, MD

University of California, Riverside/Riverside Community

Hospital, Riverside, CA, USA

\footnotetext{
A. Lakshminarasimhachar, MD · P. M. Singh, MD Department of Anesthesia, Washington University in Saint Louis, Saint Louis, MO, USA
}

Methods Various databases were searched independently for randomized-controlled trials (RCTs) comparing topical agents used for the prevention of postoperative sore throat. Inclusion criteria were parallel group studies comparing intervention with active or inactive control and reporting postoperative sore throat. The primary outcome was postoperative sore throat at $24 \mathrm{hr}$. Secondary outcomes were early sore throat at 4-6 hr, cough, and hoarseness at $24 \mathrm{hr}$.

Results Evidence was synthesized from 70 RCTs reporting 7,141 patients. Topical application of lidocaine, corticosteroids, ketamine, magnesium, benzydamine, water-based lubricant, and liquorice applied along the tracheal tube, to the tracheal tube cuff, gargled or sprayed were compared with intracuff air and each other. Bayesian NMA showed that magnesium (odds ratio [OR], 0.10; 95\% credible interval [CrI], 0.03 to 0.26), liquorice (OR, 0.14; 95\% CrI, 0.03 to 0.55), and steroid application (OR, 0.11; 95\% CrI, 0.06 to 0.22) most effectively prevented postoperative sore throat at $24 \mathrm{hr}$. Topical lidocaine was the least effective intervention.

Conclusion Topical application of magnesium followed by liquorice and corticosteroids most effectively prevented postoperative sore throat $24 \mathrm{hr}$ after endotracheal intubation.

\section{Résumé}

Contexte Le choix optimal des médicaments prophylactiques pour réduire les maux de gorge postopératoires n'est pas clair. L'objectif de cette méta- 
analyse en réseau (NMA) était de comparer et classifier 11 agents topiques utilisés pour prévenir les maux de gorge postopératoires.

Méthode Des recherches ont été réalisées dans plusieurs bases de données de façon indépendante afin d'en extraire les études randomisées contrôlées (ERC) comparant des agents topiques utilisés pour la prévention des maux de gorge postopératoires. Nos critères d'inclusion étaient des études de groupes parallèles comparant une intervention à un témoin actif ou inactif sur des résultats de maux de gorge postopératoires. Le critère d'évaluation principal était les maux de gorge postopératoires à $24 \mathrm{~h}$. Les critères d'évaluation secondaires comprenaient les maux de gorge précoces à 4-6 h, la toux et l'enrouement à $24 \mathrm{~h}$.

Résultats Les données probantes ont été synthétisées à partir de 70 ERC portant sur 7141 patients. L'application topique de lidocaïne, de corticostéroïles, de kétamine, de magnésium, de benzydamine, d'un lubrifiant à base d'eau et de la réglisse, appliqués le long du tube endotrachéal, sur le ballonnet du tube endotrachéal, en gargarisme ou en vaporisation, ont été comparées à l'air intra-ballonnet et entre les divers agents. La NMA bayésienne a démontré que l'application de magnésium (rapport de cotes [RC], 0,10; intervalle de crédibilité [CrI] $95 \%, 0,03$ à 0,26), de réglisse (RC, 0,14; CrI $95 \%, 0,03$ à 0,55) et de stéroïdes (RC, 0,11; CrI 95\%, 0,06 à 0,22) étaient les méthodes plus efficaces pour prévenir les maux de gorge postopératoires à $24 \mathrm{~h}$. La lidocaïne topique était l'intervention la moins efficace à $24 \mathrm{~h}$.

Conclusion L'application topique de magnésium, suivie de celle de réglisse et de corticostéroüdes, est l'approche qui prévient le plus efficacement les maux de gorge postopératoires 24 h après une intubation endotrachéale.

Keywords Postoperative sore throat prophylaxis ·

Cough $\cdot$ Hoarseness $\cdot$ topical agent $\cdot$ tracheal tube

Postoperative sore throat is common after general anesthesia and tracheal intubation with an incidence ranging from $21 \%$ to $68 \% .^{1,2}$ Postoperative sore throat is the second most common adverse outcome following a general anesthetic and negatively impacts patient

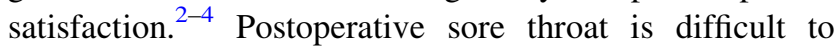
treat, even when the operative pain has been controlled by administration of systemic analgesic medications. ${ }^{5}$ Furthermore, anesthesiologists may not be aware of the incidence of sore throat in their own practice, as many patients may not seek medical advice for postoperative sore throat. ${ }^{6}$ Thus, although a minor complication, attenuation of the symptoms of sore throat in the postoperative period is a worthwhile goal.
The potential mechanisms of sore throat are thought to be irritation, mechanical trauma, and inflammation secondary to insertion of endotracheal tube (ETT) and inflation of the cuff. ${ }^{2-4,7}$ Various non-pharmacologic and pharmacologic measures have been used prophylactically to reduce the risk of this postoperative complication. Nonpharmacologic methods include using a supraglottic airway device instead of a tracheal tube, using a smaller tube, limiting cuff pressure, and using gentle oropharyngeal suctioning. ${ }^{2,4}$ Topical application of various pharmacologic agents including lidocaine, corticosteroids, ketamine, magnesium, and benzydamine has been utilized to varying degree of success. Topical application of nondrug compounds such as water-based lubricant and liquorice has been examined. A variety of routes of application have been explored including nebulization, gargling, and direct application of the agent to the ETT cuff. Inhalation of corticosteroids from metred-dose inhalers or spacer device and inflation of the tracheal tube cuff with local anesthetics and saline have also been evaluated. Yet, given the variety of different agents available, the optimal choice of agent remains unclear. Previous attempts to synthesize existing data have been limited to pairwise meta-analyses and do not provide a comprehensive enough evaluation of the evidence to make an efficacious choice. ${ }^{8-11}$ The selection of prophylactic agent, therefore, is still influenced by clinical dogma, convenience, or institutional availability.

To address this shortcoming, we performed a network meta-analysis (NMA) to pool and analyze data from randomized-controlled trials (RCTs) comparing various topical agents used for prophylaxis of sore throat in adult patients undergoing surgery with tracheal tube general anesthesia. Treatments were rank-ordered from most to least effective to guide clinicians.

\section{Methods}

The systematic review followed by NMA was reported in accordance with the Preferred Reporting Items for Systematic Reviews and Network Meta-analysis (PRISMA) guidelines. ${ }^{12}$ The review protocol was registered with PROSPERO (registration number CRD42018116448) on 29 November 2018.

Two independent reviewers (N.S. and J.M.) performed a comprehensive literature search of PubMed, Google Scholar, EMBASE, and the Cochrane central registers of controlled trial databases for abstracts, conference proceedings, and full text papers that evaluated agents used to prevent postoperative sore throat from the date of inception to 31 October 2018. To identify additional references, reviewers also hand-searched meta-analyses 
and systematic reviews and guidelines published on this topic. Our search strategy is outlined in the electronic supplement. The search was run to retrieve the relevant articles according to standard population, intervention, comparison, outcome, timing, and study design (PICOTS) criteria as follows: adult anesthesia (population), various drugs (intervention and comparison), sore throat (outcome), $24 \mathrm{hr}$ (timing), randomized-controlled trial (study design), and postoperative period (setting). Free text and MeSH terms were used individually, and in various combinations, then cross-references of articles were searched to ensure identification of all eligible studies. We placed no restriction on the language of manuscripts included.

Inclusion criteria

- Population: adults between the age of 18 and $75 \mathrm{yr}$.

- Interventions: preventive, topical application of one of the following treatments in the preoperative period among adult patients undergoing surgery under general anesthesia with single lumen tube: lidocaine, corticosteroid, ketamine, magnesium, benzydamine, water-based lubricant, and liquorice. Inhaled corticosteroids and inflation of the ETT cuff with lidocaine and $0.9 \%$ saline were also included.

- Comparator: active or non-active control (most commonly intracuff air).

- Outcome: sore throat.

- Study design: prospective, parallel, RCTs.

- Timing: $24 \mathrm{hr}$.

- Setting: postoperative period

\section{Exclusion criteria}

- Studies conducted with double lumen tube.

- Trials examining different strategies for administration of same agent.

\section{Information source}

\section{STUDY SELECTION}

Two investigators (N.S. and J.M.) independently reviewed and assessed the eligibility of studies and abstracts that were deemed eligible after review of their full text. Any discrepancies on inclusion of a trial in our final analysis were initially resolved by discussion or by harmonisation by a third independent author (P.S.).

\section{DATA EXTRACTION}

Two reviewers (N.S. and J.M.) independently extracted the data from each included manuscript using a predefined data extraction form, which was specifically designed by the review group. The following items were extracted: the trial setting (country, year of publication), participants (sample size, age, and sex), type of surgery (laparoscopy, gynecologic, orthopedics, etc.), prophylaxis (drug, dose, route and timing of administration), study design, and outcome measures. Any disagreement concerning the extracted data were resolved by discussion. Study authors were contacted in case of missing or unclear information.

\section{DATA ITEMS}

The primary outcome was the sore throat at $24 \mathrm{hr}$ following extubation. Secondary outcomes included: 1) early (4-6 hr) sore throat; 2) cough at $24 \mathrm{hr}$; and 3) hoarseness at $24 \mathrm{hr}$. A four-level grading system has been used in literature to rate the severity of the postoperative sore throat: none, mild, moderate, and severe. We used the sum of mild, moderate, and severe cases to calculate the occurrence of sore throat.

We clustered similar pharmacologic agents to organize interventions (e.g., topical applications of any corticosteroid preparations were pooled). We clustered modes of application of a given agent including gargling, nebulization, spray, and coating of the ETT cuff gel. Inhalation of corticosteroids and intracuff application of lidocaine (either non-alkalinized or alkalinized) and saline were considered separately from one another and other agents.

Risk of bias (ROB) assessment

Two independent reviewers manually reviewed all publications. Risk of bias was assessed based upon the criteria recommended by the Cochrane Collaboration (ROB2). ${ }^{13}$ This tool evaluates the ROB according to five domains: bias arising from the randomization process, bias due to deviation from intended interventions, bias due to missing data outcomes, bias in measurement of outcome, and bias in selection of reported results. The overall ROB was expressed as low risk, some concerns, or high risk. Publication bias was visually inspected using the funnel plot.

Grading the quality of evidence ${ }^{14}$

The Grading of Recommendations, Assessment, Development, and Evaluation (GRADE) tool was used to evaluate the quality of the evidence and make recommendations. Each outcome was assessed as high, 
moderate, low, and very low evidence value, depending on the design of the studies, ROB, inconsistency, indirect evidence, imprecision, and publication bias.

\section{Statistical analysis}

An NMA evaluates treatments (nodes) based upon three assumptions. "Exchangeability" assumes that included trials have very similar methodology and inclusion criterion and compare similar interventions. To uphold this, we only included RCTs with similar methodology evaluating sore throat. "Homogeneity" is an idealistic assumption that assumes there is no heterogeneity (or no diversity) across trials. In an NMA, this variation can be quantified as "heterogeneity" across each direct (pairwise comparison). The third assumption that is unique for a network analysis is "transitivity". Absolute transitivity is yet another idealistic assumption. It suggests that there is no relevant discrepancy or inconsistency between direct and indirect evidence. Deviation from transitivity in a network is measured as network "inconsistency". We evaluated this parameter in our network using net-heat and node split method. The node-splitting approach is especially attractive because inconsistency is evaluated one comparison at a time by separating the direct evidence on that comparison from the network of indirect evidence. The discrepancy between the estimates of relative treatment effects from these two sets of trials indicates the level of inconsistency. We used a Bayesian method because Bayesian inference via Markov Chain Monte Carlo (MCMC) modelling is unbiased with respect to sample size and can accommodate any sample size no matter how small. ${ }^{15}$ Frequentist inference, in contrast, becomes more biased as sample size decreases and is often wildly biased with small samples. We also planned to perform meta-regression for study level data in "Gemtc", which is Bayesian-based modelling.

For each trial, the probability of postoperative sore throat was analyzed and expressed as the odds ratio (OR) with 95\% credible interval (CrI) and whenever possible results were used from an intention-to-treat population. After extraction of required data, the evidence patterns shown by the network plot were examined to ensure that a closed network was formed by all preventive strategies and all nodes were included in the network. The pairwise association between each agent (also called the "direct estimate") was depicted by a graphical representation of the network. In the diagram, each preventive modality is represented by a node and the edge connects the agents that have been directly compared in one or more RCTs.

The Bayesian network analysis was carried out by modelling the postoperative sore throat with the Bayesian hierarchical model (binomial model with logit link function) using the MCMC approach. The Gemtc package uses vague priors [normal $(0,0.0001)$ ] for estimating the trial baselines, treatment differences, and the random-effects standard deviation [uniform $(0)$,$] . We$ ran 5,000 adaptations and 20,000 iterations with a thinning factor of 10. These parameters helped us to get a potential scale reduction factor of less than 1.05.

We used residual disseminated intravascular coagulation (DIC) comparing both random and fixed effects, which is shown in the Electronic Supplementary Material (ESM) eTable. The model constructed for evaluating DIC had 158 data points. The DIC value was 414 for the fixed effect model and 291.1 for the random effect model. The closer the DIC is to the model data points, the better the model fit. Thus, we used random-effects model for our reporting. The results from the random-effects model are presented as ORs with 95\% CrI. The Bayesian concept uses the CrI, which is a more practical concept than the confidence interval because indirect effects introduce some degree of uncertainty in pooled outcomes. For a $95 \% \mathrm{CrI}$, the value of interest (e.g., size of treatment effect) lies with a $95 \%$ probability in the interval. Unlike the confidence interval, which defines boundaries for point estimate values, the CrI defines boundaries for probability values. Lastly, the probability was calculated to be the first, the second, the third, and the worst agent and is represented in the correspondent rank order of preference.

$\mathrm{R}$ assisted by package "gemtc" (R repository, Comprehensive $\mathrm{R}$ Archive Network) was used for statistical analysis. The MCMC modelling was performed using a Gibbs sampler. For the construction of network diagram and net-heat plot, the "netmeta" package was used in R.

\section{Exploration of heterogeneity}

Network meta-analysis assumes that trials are homogeneous in measures of effect size, and generate estimates for direct and, more importantly, indirect comparisons. In reality, this assumption is rarely entirely valid because of inevitable variation in study procedures and populations. We evaluated model inconsistency using the DIC values and overall deviance for each parameter analyzed. The lower the DIC values compared with the estimated number of data points, the lower the inconsistency. We made a net-heat plot to visually inspect and locate sites of high inconsistency in our network. Further, we used a node-splitting approach to quantify variations between direct and indirect estimates at each node. 


\section{Results}

Characteristics of included studies

We identified 2,986 references and reviewed 312 full-text manuscripts. A total of 70 trials were included in the final analysis. ${ }^{5,16-84}$ The number of studies identified at each step are reported in the PRISMA diagram (Fig. 1). Two nonEnglish trials were included in the final analysis. ${ }^{46,63}$ No conference meeting abstract provided complete data that met inclusion criteria. Key information of the 70 included studies is presented in the eTable (ESM). The included studies reported the postoperative sore throat at $24 \mathrm{hr}$ in a total of 7,141 participants. Multiple groups were common among the included trials: one trial reported six groups, ${ }^{80}$ four trials reported four groups, ${ }^{24,38,40,55}$ and 19 trials reported three arms. ${ }^{16,17,23,25-27,32,39,41,45,46,48,52,53,56,62,67,72,81}$ The remaining 44 trials were simple two-arm comparisons.
Included trials were reported between 1997 and 2018 and were relatively homogeneous with regard to age, sex, intubation times, and type of surgeries within groups. Early (4-6 hr) sore throat was reported in 42 trials comprising 4,813 participants with eight comparative agents. The incidence of cough at $24 \mathrm{hr}$ was analyzed in 23 trials including 2,405 patients with ten different agents. The incidence of hoarseness at $24 \mathrm{hr}$ was studied in 24 trials with 2,600 participants employing ten active agents.

Summary of network geometry

All networks were complete, as all the nodes could be connected. The network geometry across outcomes showed a preponderance of studies comparing topical ketamine and topical steroids with the intracuff air (Fig. 2). Overall, 107 possible pairwise comparisons could be made between the 11 treatments for incidence of sore throat at $24 \mathrm{hr}$. Of these,
Fig. 1 PRISMA flow diagram of included randomizedcontrolled trials.
PRIS M
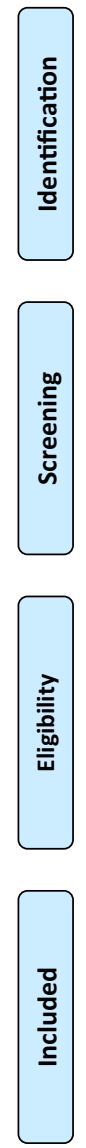

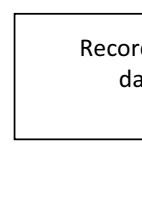

Records identified through database searching $(\mathrm{n}=2586)$

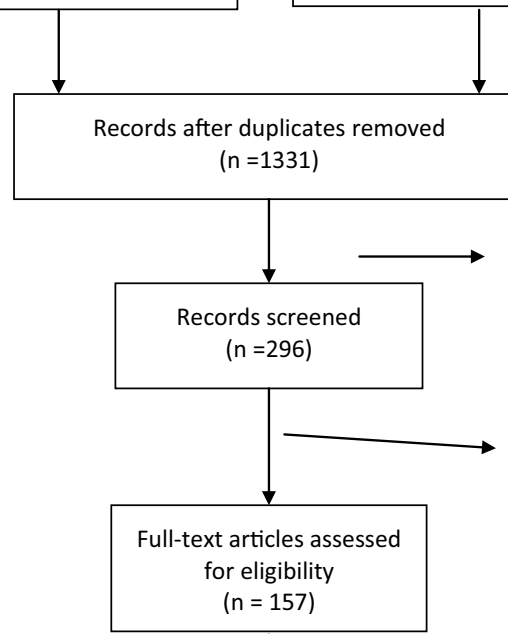

Records excluded after screening abstracts $(n=1035)$ sources $(n=48)$

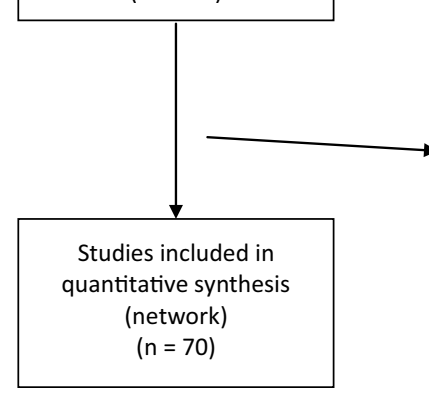

Full-text articles excluded $(n=87)$

Not relevant population $n=62$ Not relevant design $n=8$ Not relevant intervention $n=7$ Not relevant outcome $n=10$ 
Fig. 2 Network plot showing the network geometry for postoperative sore throat at 24 hr. Size of nodes corresponds to sample size of treatment group (reported in parentheses). Lines connecting the nodes show the number of trials (in parentheses) comparing the connected nodes and is proportional to the thickness of line. Benz = benzydamine; $\mathrm{IcAr}=$ intracuff air; IcLi = intracuff lidocaine; IcNS = intracuff normal saline; $\mathrm{IhSt}=$ inhaled steroid; Keta $=$ ketamine; $\mathrm{KYJe}=$ water-based lubricant; Lido = lidocaine; Liqr = liquorice; $\mathrm{Mg}=$ magnesium; Ster $=$ corticosteroid.

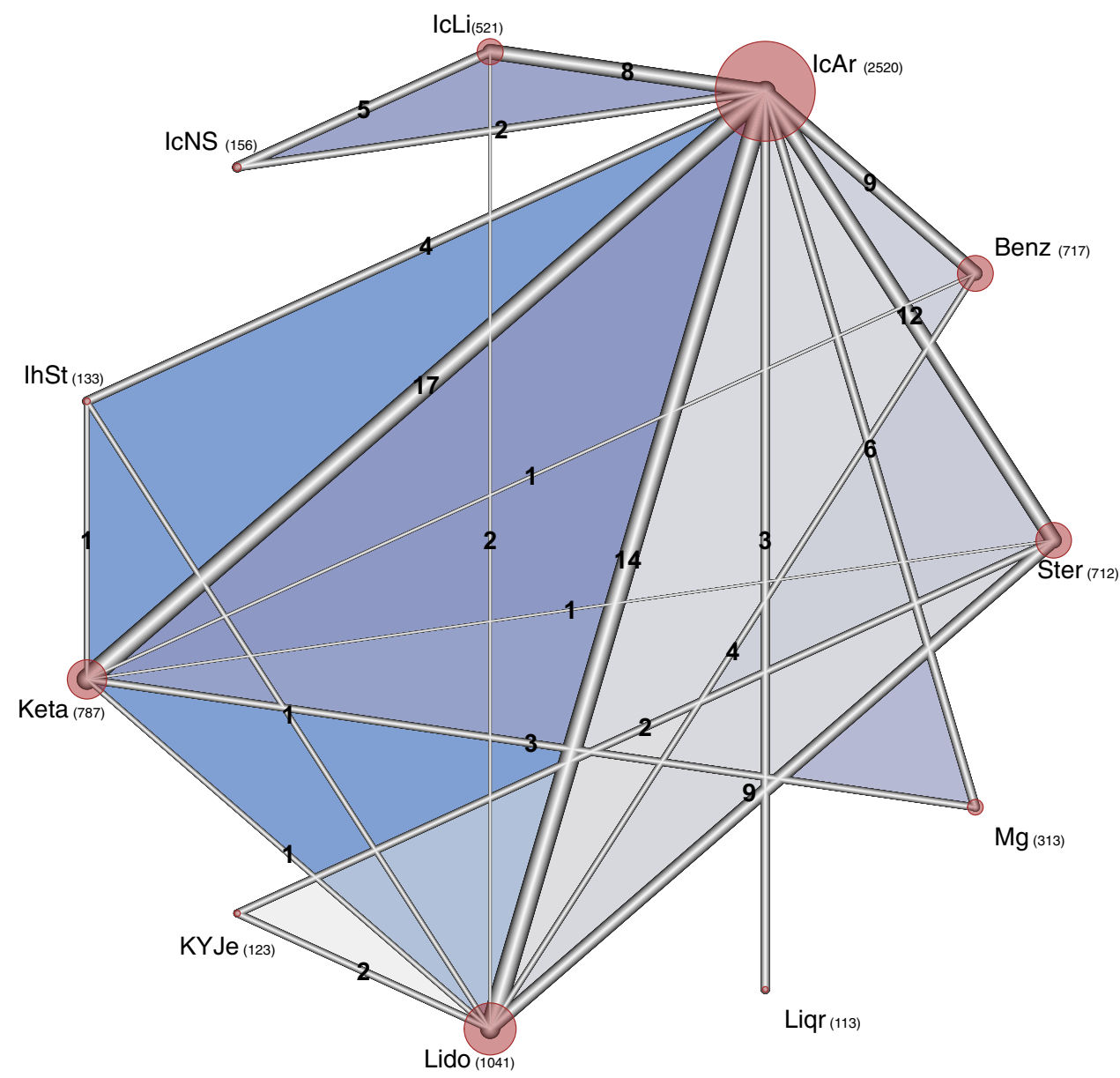

22 comparisons were formed directly by head to head evidence, but five of the direct connections had only one trial. Several comparisons had been directly studied in one or more trials of which lidocaine $(n=33)$, steroids $(n=24)$, and ketamine $(n=22)$ had the most links. The most common comparison $(n=17)$ was between ketamine and intracuff air. Network graphs and other results for secondary outcomes are discussed in subsequent sections. We noted that all secondary outcomes displayed geometry similar to the sore throat at $24 \mathrm{hr}$ and we were able to connect all the treatment nodes in all other secondary interventions.

\section{Outcome parameters}

\section{Sore throat at $24 \mathrm{hr}$}

The complete network diagram with total number of patients included in each group is shown in Fig. 2. The comparative OR for sore throat at $24 \mathrm{hr}$ with all the included agents is shown in Table 1. The rank order of preference is shown in eFig. 1 (ESM) and represents the probability of each drug occupying a given ranking. The combined probability of magnesium (OR, $0.10 ; 95 \% \mathrm{CrI}$, 0.03 to 0.26 , ranked first) and liquorice (OR, $0.14 ; 95 \%$ CrI, 0.03 to 0.55 , ranked second) for being the "best" treatment was found to be more than $55 \%$, corticosteroid application (OR, $0.11 ; 95 \% \mathrm{CrI}, 0.06$ to 0.22 ) followed them and was ranked third. Use of magnesium was associated with the lowest incidence of sore throat. The results were reported for the random-effects modelling and the DIC for this model was 291.97 (with 158 data points and a residual deviance of 165.4). Network inconsistency for sore throat was estimated based upon a net-heat plot (eFig. 2; ESM).

\section{Risk of bias}

Figure 3 presents ROB assessment of the studies for sore throat at $24 \mathrm{hr}$ included in the NMA. There were 28 studies with low ROB, 29 with high ROB, and 13 with some concerns of bias. Judgments regarding each ROB for independent study item are presented as percentages across all the included trials in Fig. 4. Risk of bias for secondary outcomes is discussed in subsequent sections. 
TABLE 1 Postoperative sore throat at $24 \mathrm{hr}$

\begin{tabular}{|c|c|c|c|c|c|c|c|c|c|c|}
\hline \multirow[t]{11}{*}{ Benzydamine } & $\begin{array}{l}7.55 \\
(3.36 \\
\text { to } \\
17.97)\end{array}$ & $\begin{array}{r}1.13(0.36 \\
\text { to } 3.53)\end{array}$ & $\begin{array}{l}2.99 \\
(0.67 \\
\text { to } \\
13.14)\end{array}$ & $\begin{array}{l}1.19(0.30 \text { to } \\
5.01)\end{array}$ & $\begin{array}{l}4.95(1.08 \\
\quad \text { to } \\
24.44)\end{array}$ & $\begin{array}{l}1.60 \\
(0.62 \\
\text { to } \\
4.37)\end{array}$ & $\begin{array}{l}5.14 \\
\quad(2.06 \\
\text { to } \\
13.37)\end{array}$ & $\begin{array}{l}1.06 \\
(0.21 \\
\text { to } \\
5.26)\end{array}$ & $\begin{array}{r}0.75(0.20 \\
\text { to } 2.71)\end{array}$ & $\begin{array}{l}0.86(0.32 \text { to } \\
2.44)\end{array}$ \\
\hline & $\begin{array}{l}\text { Intracuff } \\
\text { air }\end{array}$ & $\begin{array}{r}0.15(0.07 \\
\text { to } 0.32)\end{array}$ & $\begin{array}{l}0.40 \\
(0.12 \\
\text { to } \\
1.32)\end{array}$ & $\begin{array}{l}0.16(0.05 \text { to } \\
0.51)\end{array}$ & $\begin{array}{r}0.65(0.16 \\
\text { to } 2.53)\end{array}$ & $\begin{array}{l}0.21 \\
\quad(0.12 \\
\text { to } \\
0.37)\end{array}$ & $\begin{array}{l}0.68 \\
\quad(0.38 \\
\text { to } \\
1.20)\end{array}$ & $\begin{array}{l}0.14 \\
\quad(0.03 \\
\text { to } \\
0.55)\end{array}$ & $\begin{array}{r}0.10(0.03 \\
\text { to } 0.26)\end{array}$ & $\begin{array}{l}0.11(0.06 \text { to } \\
0.22)\end{array}$ \\
\hline & & $\begin{array}{l}\text { Intracuff } \\
\text { lidocaine }\end{array}$ & $\begin{array}{l}2.67 \\
\quad(0.90 \\
\text { to } \\
7.93)\end{array}$ & $\begin{array}{l}1.06(0.26 \text { to } \\
4.38)\end{array}$ & $\begin{array}{l}4.37(0.95 \\
\quad \text { to } \\
21.15)\end{array}$ & $\begin{array}{l}1.43 \\
\quad(0.54 \\
\text { to } \\
3.70)\end{array}$ & $\begin{array}{l}4.56 \\
(1.85 \\
\text { to } \\
11.65)\end{array}$ & $\begin{array}{l}0.93 \\
\quad(0.18 \\
\text { to } \\
4.63)\end{array}$ & $\begin{array}{r}0.67(0.18 \\
\text { to } 2.41)\end{array}$ & $\begin{array}{l}0.77 \text { ( } 0.29 \text { to } \\
2.09)\end{array}$ \\
\hline & & & $\begin{array}{c}\text { Intracuff } \\
0.9 \% \\
\text { saline }\end{array}$ & $\begin{array}{l}0.40(0.07 \text { to } \\
2.12)\end{array}$ & $\begin{array}{l}1.67(0.27 \\
\text { to } \\
10.05)\end{array}$ & $\begin{array}{l}0.54 \\
(0.14 \\
\text { to } \\
2.04)\end{array}$ & $\begin{array}{l}1.74 \\
(0.45 \\
\text { to } \\
6.37)\end{array}$ & $\begin{array}{l}0.35 \\
\quad(0.05 \\
\text { to } \\
2.33)\end{array}$ & $\begin{array}{r}0.25(0.05 \\
\text { to } 1.18)\end{array}$ & $\begin{array}{l}0.29(0.07 \text { to } \\
1.07)\end{array}$ \\
\hline & & & & $\begin{array}{l}\text { Inhaled } \\
\quad \text { corticosteroids }\end{array}$ & $\begin{array}{l}4.15(0.71 \\
\quad \text { to } \\
23.99)\end{array}$ & $\begin{array}{l}1.35 \\
(0.37 \\
\text { to } \\
4.64)\end{array}$ & $\begin{array}{l}4.34 \\
(1.20 \\
\text { to } \\
15.40)\end{array}$ & $\begin{array}{l}0.89 \\
\quad(0.14 \\
\text { to } \\
5.46)\end{array}$ & $\begin{array}{r}0.62(0.13 \\
\text { to } 2.89)\end{array}$ & $\begin{array}{l}0.72(0.19 \text { to } \\
2.74)\end{array}$ \\
\hline & & & & & $\begin{array}{l}\text { Water- } \\
\text { based } \\
\text { lubricant }\end{array}$ & $\begin{array}{l}0.33 \\
\quad(0.07 \\
\text { to } \\
1.39)\end{array}$ & $\begin{array}{l}1.03 \\
\quad(0.28 \\
\text { to } \\
3.92)\end{array}$ & $\begin{array}{l}0.21 \\
(0.03 \\
\text { to } \\
1.41)\end{array}$ & $\begin{array}{r}0.15(0.03 \\
\text { to } 0.86)\end{array}$ & $\begin{array}{l}0.17 \text { (0.05 to } \\
0.66)\end{array}$ \\
\hline & & & & & & Ketamine & $\begin{array}{l}3.20 \\
\quad(1.48 \\
\text { to } \\
7.12)\end{array}$ & $\begin{array}{l}0.66 \\
\quad(0.14 \\
\text { to } \\
2.97)\end{array}$ & $\begin{array}{r}0.47(0.15 \\
\text { to } 1.36)\end{array}$ & $\begin{array}{l}0.54(0.23 \text { to } \\
1.28)\end{array}$ \\
\hline & & & & & & & Lidocaine & $\begin{array}{l}0.20 \\
(0.04 \\
\text { to } \\
0.93)\end{array}$ & $\begin{array}{r}0.15(0.04 \\
\text { to } 0.46)\end{array}$ & $\begin{array}{l}0.17 \text { (0.08 to } \\
0.33)\end{array}$ \\
\hline & & & & & & & & Liquorice & $\begin{array}{r}0.71(0.12 \\
\text { to } 4.11)\end{array}$ & $\begin{array}{l}0.82(0.18 \text { to } \\
3.84)\end{array}$ \\
\hline & & & & & & & & & Magnesium & $\begin{array}{l}1.15 \text { ( } 0.36 \text { to } \\
3.90)\end{array}$ \\
\hline & & & & & & & & & & Corticosteroid \\
\hline
\end{tabular}

Quantities reported are odds ratios with $95 \%$ credible intervals combining direct/indirect estimates. Both point estimates and credible intervals are considered when ranking treatments

\section{Publication bias}

We constructed a funnel plot for pairwise comparisons (using $\mathrm{R}$ software) to visually inspect publication bias. Most trials were symmetrically distributed and no obvious publication bias was noted (Fig. 5).

\section{Inconsistency}

To estimate/locate network inconsistency, we used net-heat plot and node-splitting analysis. Net-heat (eFig. 2; ESM) helped us estimate contribution of a direct comparison in the overall pairwise comparison result (that includes both indirect and direct estimate). It also helped us to estimate the inconsistency contributed by individual comparison to the overall network. The node split model compared pairwise direct, indirect, and network estimates for all the treatments. For all comparisons, both direct and indirect values corroborated well. No $P$ values evaluating differences between direct and indirect estimates were statistically significant (Fig. 6).

Our results showed that, after combining the evidence from direct and indirect estimates, magnesium was the best prophylactic agent for prevention of postoperative sore throat at $24 \mathrm{hr}$ and had a $36 \%$ probability of being the best treatment. There were negligible $(0 \%)$ chances of magnesium being the worst agent. Liquorice ranked second with a $19.2 \%$ probability of being the best, and 
Fig. 3 Risk of bias summary for postoperative sore throat at $24 \mathrm{hr}$.

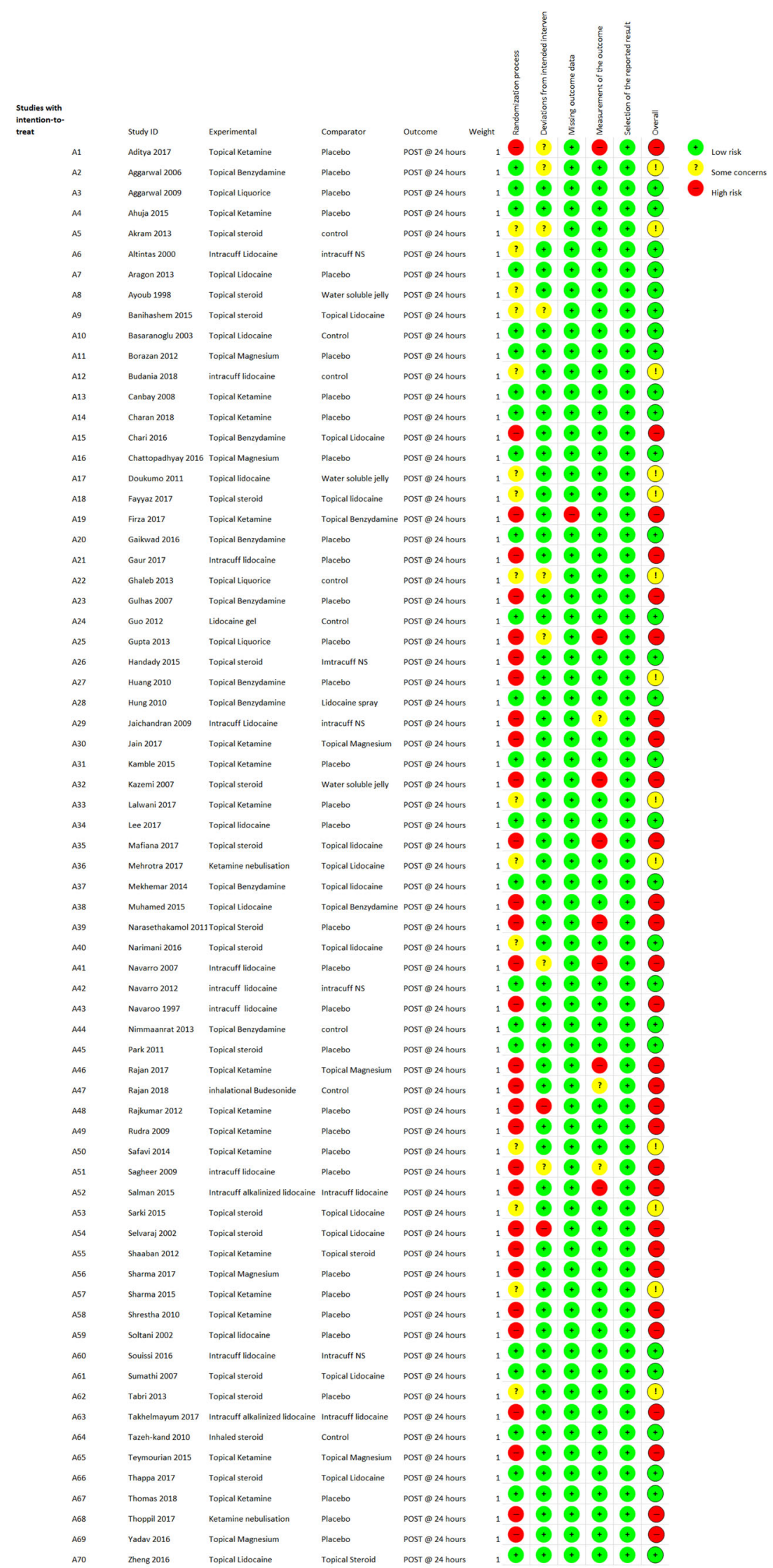




\section{As percentage (intention-to-treat)}

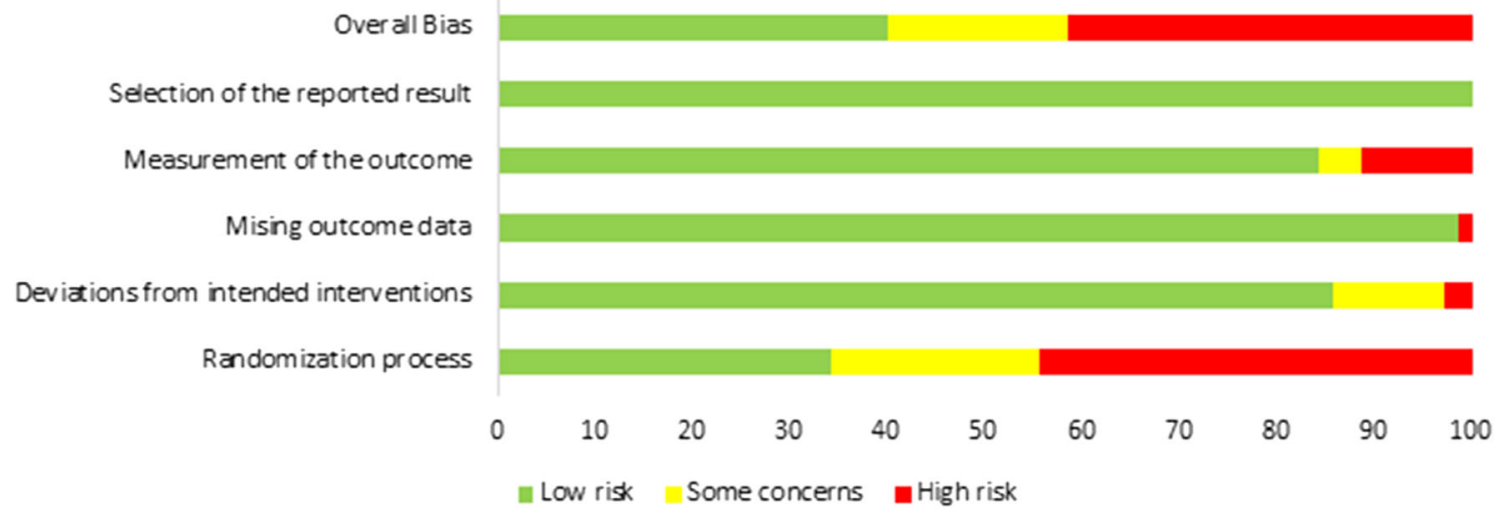

Fig. 4 Risk of bias bar chart for postoperative sore throat at $24 \mathrm{hr}$. The colours in the bars next to each row/criterion represent percentage of total studies falling within the high/low/some concerns category. funnel plots of publication bias for postoperative sore throat at $24 \mathrm{hr}$. Benz = benzydamine; $\mathrm{IcAr}=$ intracuff air; IcLi $=$ intracuff lidocaine; IcNS = intracuff normal saline; IhSt $=$ inhaled steroid; Keta $=$ ketamine; KYJe = water-based lubricant; Lido = lidocaine; Liqr = liquorice; $\mathrm{Mg}=$ magnesium; Ster $=$ corticosteroid
Fig. 5 Comparison-adjusted

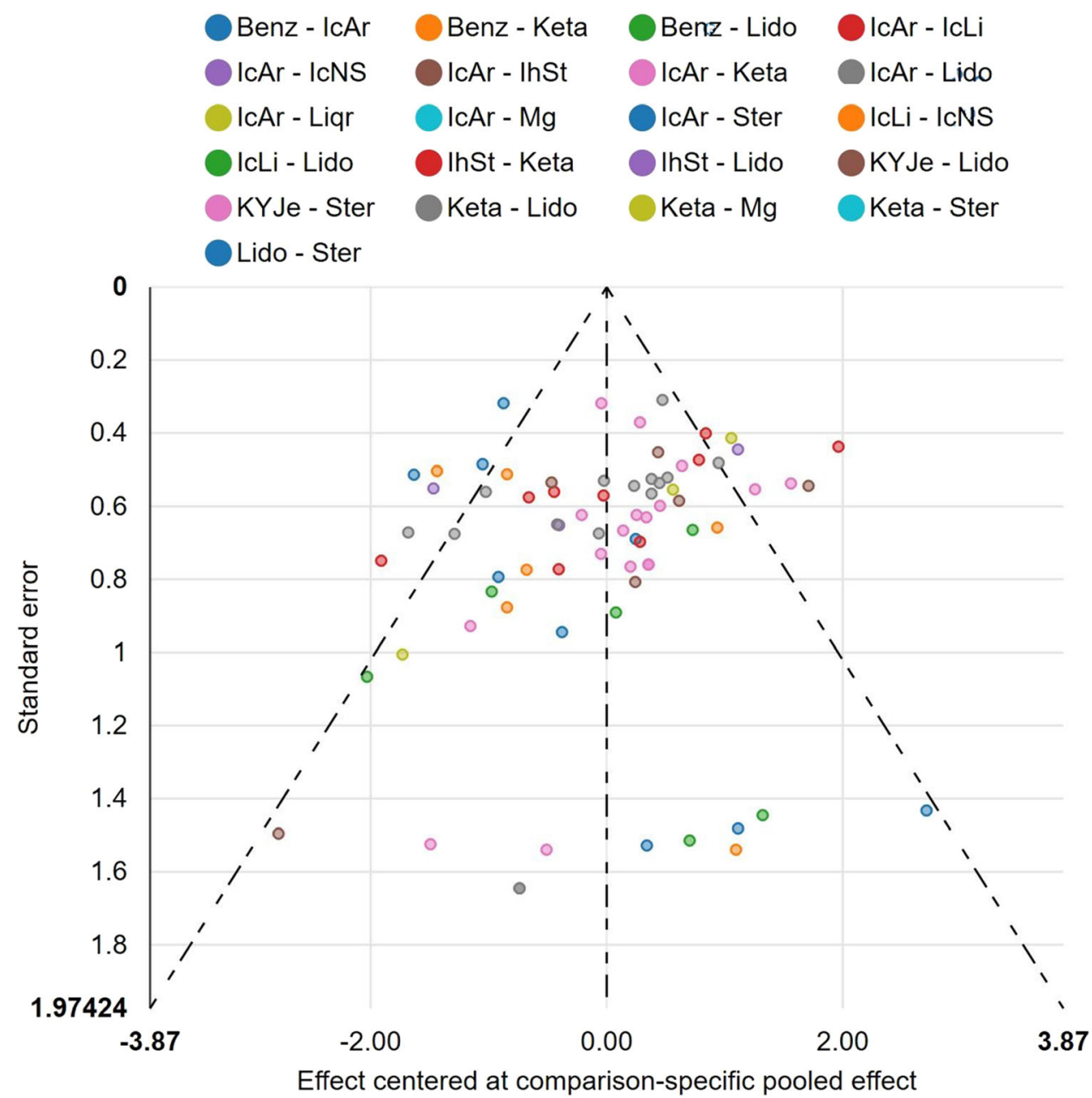

corticosteroids ranked third with a $14.4 \%$ probability of being the best prophylactic agent for postoperative sore of evidence was low because of inconsistency, imprecision, and indirectness among the included trials (Table 2). 
Fig. 6 Forest plot showing direct, indirect, and network estimates of effect for pairwise comparisons of interventions for postoperative sore throat at 24 hr. Benz = benzydamine; IcAr = intracuff air; IcLi = intracuff lidocaine; IcNS = intracuff normal saline; IhSt $=$ inhaled steroid; Keta = ketamine; KYJe = water-based lubricant; Lido = lidocaine; $\mathrm{Mg}=$ magnesium;

Ster $=$ corticosteroid .

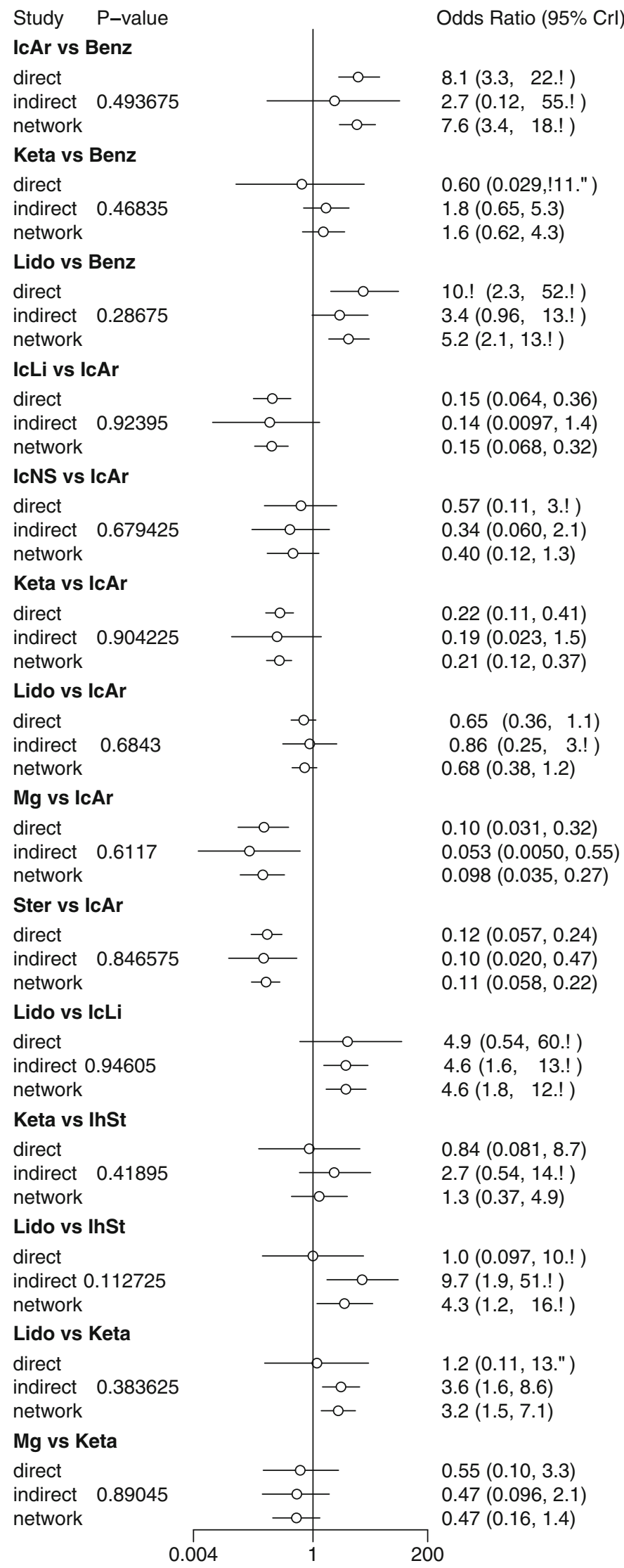


Fig. 6 continued

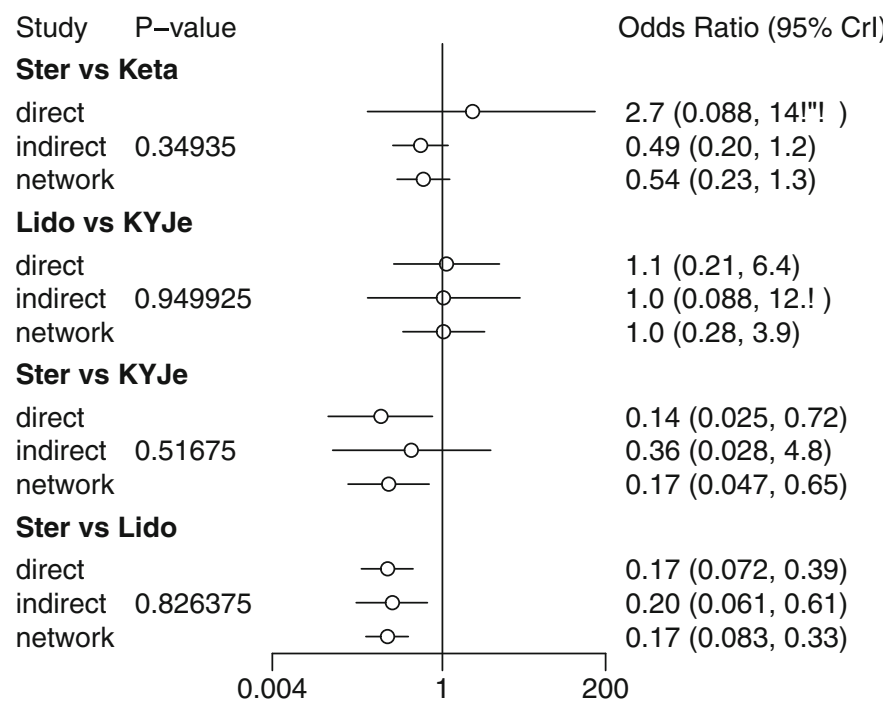

Sore throat at $4-6 \mathrm{hr}$

Hoarseness at $24 \mathrm{hr}$

We were able to include eight treatment nodes (42 trials) in our network for this parameter and included a total of 4,813 patients (eFig. 3; ESM). The comparative absolute OR values for early sore throat are shown in Table 3. Inhaled corticosteroids (OR, 0.03 ; 95\% CrI, 0.00 to 0.33 ) appeared to be associated with lowest early sore throat with a $92.13 \%$ probability of being the best treatment. A randomeffects model was used for this parameter with a DIC of 172.22 (with 91 data points and a residual deviance of 93.7). The rank order of preference for grading all the included treatments and estimated network inconsistency based upon the net-heat plot are shown in eFigs 4 and 5 (ESM), respectively. Risk of bias across the studies is reported in eFig. 6 (ESM).

\section{Cough at $24 \mathrm{hr}$}

The network for cough at $24 \mathrm{hr}$ included ten treatment nodes (23 trials) with a total of 2,405 patients (eFig. 7; ESM). The comparative OR of cough for all treatment groups is shown in Table 4. Liquorice (OR, 0.00; 95\% CrI, 0.00 to 0.28 ) was associated with the lowest occurrence of cough at $24 \mathrm{hr}(60.77 \%$ probability of being the best treatment). The combined probability of liquorice and benzydamine for being the best treatment associated with lowest incidence of cough was $99.66 \%$. The DIC for the random-effects modelling for this parameter was 98.13 (with 57 data points and residual deviance of 52.9). The rank order of preference for grading all the included treatments for this parameter is shown in eFig. 8 (ESM). Model inconsistency was evaluated using the net-heat plot shown in eFig. 9 (ESM). Risk of bias across the studies is presented in eFig. 10 (ESM).

We were able to construct a network for this outcome with ten treatment nodes (24 trials) and a total of 2,600 patients (eFig. 11; ESM). The OR for hoarseness after each treatment is shown in Table 5. Use of magnesium (OR, $0.00 ; 95 \% \mathrm{CrI}, 0.00$ to $>100)$ was associated with the lowest hoarseness and had a $73.63 \%$ probability of being the best agent. Results are reported based on the randomeffects model with a DIC of 97.59 (with 58 data points and a residual deviance of 53.8). The relative grading of treatments in terms of treatment efficacy is shown in eFig. 12 (ESM). We evaluated the network inconsistency using the net-heat plot as shown in eFig. 13 (ESM), and ROB across the studies is presented in eFig. 14 (ESM).

Quality of evidence and recommendations

We prepared a summary of finding (SoF) table based on GRADE Pro recommendations comparing all the active treatments with the control (intracuff air) for all the outcomes. The evidence shows that use of any active agent was beneficial compared with the control, but the quality of this was low for the primary and secondary outcomes (Table 6). The direct estimate was assessed using the ROB, inconsistency, and publication bias. The final pooled mixed estimate was assessed using the rating of the direct estimate (if high and dominant in contribution) followed by assessment for incoherence and imprecision.

\section{Discussion}

Our NMA provides a comprehensive synthesis of evidence for topical prophylactic treatment of sore throat in adult 
TABLE 2 Postoperative sore throat at $24 \mathrm{hr}$ network meta-analysis summary of finding table

\begin{tabular}{|c|c|c|c|c|c|c|}
\hline \multicolumn{7}{|c|}{$\begin{array}{l}\text { Patients: Adult (18-75 years) undergoing surgery with endotracheal tube } \\
\text { Intervention: Multiple topical agents } \\
\text { Comparator (Reference): Intracuff air } \\
\text { Outcome: sore throat } \\
\text { Timing: } 24 \text { hours }\end{array}$} \\
\hline \multicolumn{7}{|c|}{ Setting: Postoperative period } \\
\hline \multirow{2}{*}{$\begin{array}{l}\text { Total studies (Total } \\
\text { population): }\end{array}$} & \multicolumn{3}{|c|}{ Anticipated absolute effect $(95 \% \mathrm{CrI})$} & \multirow{2}{*}{$\begin{array}{l}\text { Relative effect } \\
(95 \% \text { CrI })\end{array}$} & \multirow{2}{*}{$\begin{array}{l}\text { Certainty of } \\
\text { evidence }\end{array}$} & \multirow{2}{*}{$\begin{array}{l}\text { Probability } \\
\text { Best Treatment } \\
\text { Worst Treatment }\end{array}$} \\
\hline & $\begin{array}{l}\text { Without } \\
\text { intervention }\end{array}$ & $\begin{array}{l}\text { With } \\
\text { intervention }\end{array}$ & Odds Ratio & & & \\
\hline $\begin{array}{l}\text { Magnesium } \\
\text { (6 RCTs; } 511 \text { participants) }\end{array}$ & $221 / 1000$ & $45 / 1000$ & $\begin{array}{c}0.17 \\
(0.09 \text { to } 0.32)\end{array}$ & $\begin{array}{l}0.10(0.03 \text { to } 0.26) \\
\text { Network estimate }\end{array}$ & $\begin{array}{l}\oplus \oplus \mathrm{LOW}_{\dagger} \\
\end{array}$ & 0.36 \\
\hline $\begin{array}{l}\text { Liquorice } \\
\text { (3 RCTs; } 197 \text { participants) }\end{array}$ & $724 / 1000$ & $353 / 1000$ & $\begin{array}{c}0.21 \\
(0.11 \text { to } 0.38)\end{array}$ & $\begin{array}{l}0.14(0.03 \text { to } 0.55) \\
\text { Network estimate }\end{array}$ & 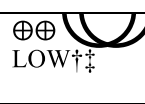 & $\begin{array}{l}0.192 \\
0.003\end{array}$ \\
\hline $\begin{array}{l}\text { Corticosteroids } \\
\text { (12 RCTs; } 1086 \text { participants) }\end{array}$ & $651 / 1000$ & $178 / 1000$ & $\begin{array}{c}0.12 \\
(0.09 \text { to } 0.15)\end{array}$ & $\begin{array}{l}0.11(0.06 \text { to } 0.22) \\
\text { Network estimate }\end{array}$ & $\begin{array}{l}\oplus \oplus \mathrm{LOW}^{+} \\
\end{array}$ & $\begin{array}{l}0.144 \\
0.00\end{array}$ \\
\hline $\begin{array}{l}\text { Benzydamine } \\
\text { (9 RCTs; } 1192 \text { participants) }\end{array}$ & $255 / 1000$ & $72 / 1000$ & $\begin{array}{c}0.23 \\
(0.16 \text { to } 0.32)\end{array}$ & $\begin{array}{l}0.13(0.30 \text { to } 0.06) \\
\text { Network estimate }\end{array}$ & $\begin{array}{l}\oplus \oplus \mathrm{LOW}_{\dagger} \\
\end{array}$ & $\begin{array}{l}0.12 \\
0.000\end{array}$ \\
\hline $\begin{array}{l}\text { Inhaled corticosteroids } \\
\text { (4 RCTs; } 266 \text { participants) }\end{array}$ & $436 / 1000$ & $127 / 1000$ & $\begin{array}{c}0.19 \\
(0.10 \text { to } 0.35)\end{array}$ & $\begin{array}{l}0.16(0.05 \text { to } 0.51) \\
\text { Network estimate }\end{array}$ & $\begin{array}{l}\oplus \oplus \backslash \\
\text { LOW }\end{array}$ & 0.112 \\
\hline $\begin{array}{l}\text { Intracuff lidocaine } \\
\text { (7 RCTs; } 691 \text { participants) }\end{array}$ & $534 / 1000$ & $181 / 1000$ & $\begin{array}{c}0.19 \\
(0.13 \text { to } 0.27)\end{array}$ & $\begin{array}{l}0.15(0.07 \text { to } 0.32) \\
\text { Network estimate }\end{array}$ & $\begin{array}{l}\oplus \oplus \mathrm{LOW}_{+} \\
\end{array}$ & $\begin{array}{l}0.065 \\
0.000\end{array}$ \\
\hline $\begin{array}{l}\text { Intracuff } 0.9 \% \text { Saline } \\
\text { (2 RCTs; } 155 \text { participants) }\end{array}$ & $610 / 1000$ & $483 / 1000$ & $\begin{array}{c}0.60 \\
(0.31 \text { to } 1.15)\end{array}$ & $\begin{array}{l}0.40(0.12 \text { to } 1.32) \\
\text { Network estimate }\end{array}$ & $\begin{array}{l}\oplus \oplus \backslash \\
\text { LOW }\end{array}$ & $\begin{array}{l}0.004 \\
0.046\end{array}$ \\
\hline $\begin{array}{l}\text { Ketamine } \\
\text { (17 RCTs; } 1377 \text { participants) }\end{array}$ & $364 / 1000$ & $137 / 1000$ & $\begin{array}{c}0.28 \\
(0.21 \text { to } 0.36)\end{array}$ & $\begin{array}{l}0.21(0.12 \text { to } 0.37) \\
\text { Network estimate }\end{array}$ & $\begin{array}{l}\oplus \oplus \bigcup \\
\text { LOW }\end{array}$ & $\begin{array}{l}0.002 \\
0.000\end{array}$ \\
\hline $\begin{array}{l}\text { Water soluble jelly } \\
\text { (No direct evidence, indirect } \\
\text { evidence only) }\end{array}$ & No trials & No trials & $\begin{array}{l}\text { Not } \\
\text { estimatable }\end{array}$ & $\begin{array}{l}0.65(0.16 \text { to } 2.53) \\
\text { Network estimate }\end{array}$ & $\begin{array}{l}\oplus \oplus \mathrm{LOW}_{\dagger} \\
\mathrm{Lu}\end{array}$ & $\begin{array}{l}0.001 \\
0.256 \\
\end{array}$ \\
\hline $\begin{array}{l}\text { Lidocaine } \\
\text { (14 RCTs; } 1350 \text { participants) }\end{array}$ & $379 / 1000$ & $313 / 1000$ & $\begin{array}{c}0.75 \\
(0.60 \text { to } 0.94)\end{array}$ & $\begin{array}{l}0.68(0.38 \text { to } 1.20) \\
\text { Network estimate }\end{array}$ & $\oplus \oplus \bigcup_{\text {LOW }+t}$ & $\begin{array}{l}0.000 \\
0.052\end{array}$ \\
\hline Intracuff air & No estimable & No estimable & No estimable & $\begin{array}{l}\text { Reference } \\
\text { comparator }\end{array}$ & $\begin{array}{l}\text { Reference } \\
\text { comparator }\end{array}$ & $\begin{array}{l}0.000 \\
0.642\end{array}$ \\
\hline \multicolumn{7}{|c|}{$\begin{array}{l}\text { Rows represent direct comparisons } \\
* * * \text { Estimates are reported as odds ratio. CrI: credible interval. } \\
\dagger \text { Inconsistency } \\
\ddagger \text { Imprecision } \\
\vdots \text { Indirectness }\end{array}$} \\
\hline
\end{tabular}


TABLE 3 Postoperative sore throat at $4-6 \mathrm{hr}$

\begin{tabular}{|c|c|c|c|c|c|c|c|}
\hline \multirow[t]{8}{*}{ Benzydamine } & $\begin{array}{c}5.00(2.38 \text { to } \\
10.53)\end{array}$ & $\begin{array}{l}0.12(0.01 \text { to } \\
1.87)\end{array}$ & $\begin{array}{c}11.69(1.32 \text { to } \\
110.41)\end{array}$ & $\begin{array}{l}1.22(0.50 \text { to } \\
2.95)\end{array}$ & $\begin{array}{c}5.02(2.11 \text { to } \\
11.82)\end{array}$ & $\begin{array}{l}1.29(0.42 \text { to } \\
4.23)\end{array}$ & $\begin{array}{l}1.72(0.65 \text { to } \\
4.54)\end{array}$ \\
\hline & Intracuff air & $\begin{array}{l}0.03 \text { ( } 0.00 \text { to } \\
0.33)\end{array}$ & $\begin{array}{l}2.38(0.28 \text { to } \\
20.44)\end{array}$ & $\begin{array}{l}0.24(0.14 \text { to } \\
0.43)\end{array}$ & $\begin{array}{l}1.01(0.50 \text { to } \\
1.97)\end{array}$ & $\begin{array}{l}0.26(0.11 \text { to } \\
0.65)\end{array}$ & $\begin{array}{l}0.35(0.17 \text { to } \\
0.70)\end{array}$ \\
\hline & & $\begin{array}{l}\text { Inhaled } \\
\text { corticosteroids }\end{array}$ & $\begin{array}{c}94.05(3.66 \text { to } \\
147.93)\end{array}$ & $\begin{array}{c}9.89(0.71 \text { to } \\
158.08)\end{array}$ & $\begin{array}{l}40.19(2.79 \text { to } \\
711.38)\end{array}$ & $\begin{array}{l}10.38(0.67 \text { to } \\
201.36)\end{array}$ & $\begin{array}{l}13.70(0.96 \text { to } \\
237.51)\end{array}$ \\
\hline & & & $\begin{array}{c}\text { Water-based } \\
\text { lubricant }\end{array}$ & $\begin{array}{c}0.10(0.01 \text { to } \\
0.90)\end{array}$ & $\begin{array}{l}0.43(0.05 \text { to } \\
3.46)\end{array}$ & $\begin{array}{l}0.11(0.01 \text { to } \\
1.13)\end{array}$ & $\begin{array}{l}0.15(0.02 \text { to } \\
1.18)\end{array}$ \\
\hline & & & & Ketamine & $\begin{array}{l}4.11 \text { (1.71 to } \\
9.89)\end{array}$ & $\begin{array}{l}1.05 \text { ( } 0.41 \text { to } \\
2.81)\end{array}$ & $\begin{array}{l}1.41(0.56 \text { to } \\
3.35)\end{array}$ \\
\hline & & & & & Lidocaine & $\begin{array}{c}0.26(0.09 \text { to } \\
0.80)\end{array}$ & $\begin{array}{l}0.34(0.15 \text { to } \\
0.76)\end{array}$ \\
\hline & & & & & & Magnesium & $\begin{array}{c}1.33(0.42 \text { to } \\
4.09)\end{array}$ \\
\hline & & & & & & & Corticosteroids \\
\hline
\end{tabular}

Quantities reported are $95 \%$ credible intervals of the final odds ratios combining direct/indirect estimates. Both point estimates and credible intervals are considered when ranking treatments.

patients undergoing surgery with an ETT. Our results revealed that magnesium, liquorice, and corticosteroid were the three topical agents most associated with a decreased postoperative sore throat.

Efficacy of preoperative topical administration of magnesium sulfate in preventing sore throat in adult patients was recently examined in two meta-analyses. ${ }^{85,86}$ Singh et al. ${ }^{85}$ have reported that the number needed to treat was around five indicating a large prophylactic effect. No statistical heterogeneity was found for incidence of sore throat by both authors. We identified few direct comparisons of topical magnesium and other active treatments; however, our network analysis provided indirect evidence of superior efficacy of topical magnesium. The clinical utility of topical magnesium is limited by the absence of a commercially available preparation in North America and the United Kingdom and by the limited knowledge of its utility among healthcare professionals.

Topical lidocaine, applied as a jelly or spray, was associated with a high probability of being the worst outcome. Lidocaine jelly used in various trials contained additives like chlorhexidine gluconate, methyl hydroxybenzoate, and propyl hydroxybenzoate for antiseptic effect. ${ }^{87,88}$ These additives can cause hypersensitivity reactions or induce allergic dermatitis. Further, they may form dry sediments in the trachea, which irritate the airway and increase sore throat. Similarly various additives or the alkalized solvents added to lidocaine spray might have added to the damage inflicted on the tracheal mucosa during intubation, thus negating the membrane stabilizing effect of lidocaine, resulting in increased incidence of sore throat. ${ }^{89}$ Though an initial meta-analysis ${ }^{10}$ reported efficacy of topical lidocaine in reducing sore throat, a recent update by Liao et al. ${ }^{90}$ found that lidocaine lubricants in jelly, ointment, or spray, if not harmful, were are not effective in preventing postoperative sore throat.

On the other hand, when administered as a cuff inflation medium, lidocaine ranked above lidocaine jelly and spray. Cuff inflation exerts a continuous topical anesthetic effect. Also, unlike air, intracuff lidocaine was not associated with an increase in the cuff pressure due to diffusion of nitrous oxide. $^{91}$ Further, absence of any additives in intracuff lidocaine solution prevents further damage.

Our analysis has a number of limitations. Unlike a conventional meta-analysis, networks rely heavily on making indirect estimates, so credibility intervals often overlap. As a result, networks give probability of a rank order rather than an absolute rank order. Thus, readers must exercise caution when interpreting these findings. Further, it is often not possible to define "prior distributions" in Bayesian NMA, and calculations are needed to derive large standard deviation values from the available data. This may compromise precision of results. Also, most Bayesian NMA software does not allow for robust exploration of network inconsistency. We attempted to overcome this limitation with the use of a net-heat plot (frequentist approach) and node split model (Bayesian approach). Further, based on fitting of a logistic regression model using an MCMC algorithm, one can obtain estimates of the posterior distributions of not only the regression coefficients $(\beta)$ but also any function of the regression 
TABLE 4 Cough at $24 \mathrm{hr}$

\begin{tabular}{|c|c|c|c|c|c|c|c|c|c|}
\hline \multirow[t]{10}{*}{ Benzydamine } & $\begin{aligned}> & 100 \\
& (8.01 \text { to } \\
& >100)\end{aligned}$ & $\begin{array}{c}>100(1.47 \\
\quad \text { to } \\
\quad>100)\end{array}$ & $\begin{array}{c}>100(1.32 \text { to } \\
>100)\end{array}$ & $\begin{aligned}> & 100 \\
& (15.72 \text { to } \\
& >100)\end{aligned}$ & $\begin{aligned}> & 100 \\
& (2.01 \text { to } \\
& >100)\end{aligned}$ & $\begin{aligned}> & 100 \\
& (6.59 \text { to } \\
& >100)\end{aligned}$ & $\begin{array}{l}0.00(0.00 \\
\quad \text { to } \\
\quad>100)\end{array}$ & $\begin{aligned}> & 100 \\
& (0.39 \text { to } \\
& >100)\end{aligned}$ & $\begin{array}{c}>100(2.42 \text { to } \\
>100)\end{array}$ \\
\hline & $\begin{array}{l}\text { Intracuff } \\
\text { air }\end{array}$ & $\begin{array}{r}0.24(0.03 \\
\text { to } 1.72)\end{array}$ & $\begin{array}{l}0.20(0.03 \text { to } \\
1.40)\end{array}$ & $\begin{array}{c}2.08(0.41 \text { to } \\
10.15)\end{array}$ & $\begin{array}{r}0.31(0.06 \\
\text { to } 1.74)\end{array}$ & $\begin{array}{r}0.83(0.32 \\
\text { to } 2.10)\end{array}$ & $\begin{array}{r}0.00(0.00 \\
\text { to } 0.28)\end{array}$ & $\begin{array}{r}0.07(0.01 \\
\text { to } 0.84)\end{array}$ & $\begin{array}{l}0.30(0.14 \text { to } \\
0.66)\end{array}$ \\
\hline & & $\begin{array}{l}\text { Intracuff } \\
\text { lidocaine }\end{array}$ & $\begin{array}{l}0.80(0.05 \text { to } \\
12.95)\end{array}$ & $\begin{array}{c}8.75(0.71 \text { to } \\
117.84)\end{array}$ & $\begin{array}{l}1.31(0.09 \\
\text { to } 18.30)\end{array}$ & $\begin{array}{l}3.45(0.39 \\
\text { to } 33.03)\end{array}$ & $\begin{array}{r}0.00(0.00 \\
\text { to } 1.31)\end{array}$ & $\begin{array}{r}0.28(0.01 \\
\text { to } 7.38)\end{array}$ & $\begin{array}{l}1.27(0.14 \text { to } \\
11.03)\end{array}$ \\
\hline & & & $\begin{array}{l}\text { Inhaled } \\
\text { corticosteroids }\end{array}$ & $\begin{array}{l}10.93(0.84 \\
\text { to } 145.75)\end{array}$ & $\begin{array}{l}1.63(0.11 \\
\text { to } 25.48)\end{array}$ & $\begin{array}{l}4.26(0.48 \\
\text { to } 40.65)\end{array}$ & $\begin{array}{r}0.00(0.00 \\
\text { to } 1.48)\end{array}$ & $\begin{array}{r}0.35(0.01 \\
\quad \text { to } 9.25)\end{array}$ & $\begin{array}{c}1.56(0.19 \text { to } \\
13.60)\end{array}$ \\
\hline & & & & $\begin{array}{c}\text { Water-based } \\
\text { lubricant }\end{array}$ & $\begin{array}{l}0.15(0.02 \\
\text { to } 1.5)\end{array}$ & $\begin{array}{r}0.40(0.09 \\
\text { to } 1.85)\end{array}$ & $\begin{array}{r}0.00(0.00 \\
\text { to } 0.13)\end{array}$ & $\begin{array}{r}0.03(0.00 \\
\text { to } 0.68)\end{array}$ & $\begin{array}{l}0.15(0.03 \text { to } \\
0.65)\end{array}$ \\
\hline & & & & & Ketamine & $\begin{array}{l}2.64(0.37 \\
\text { to } 17.93)\end{array}$ & $\begin{array}{r}0.00(0.00 \\
\text { to } 0.82)\end{array}$ & $\begin{array}{r}0.21(0.01 \\
\text { to } 4.22)\end{array}$ & $\begin{array}{l}0.96(0.16 \text { to } \\
5.90)\end{array}$ \\
\hline & & & & & & Lidocaine & $\begin{array}{r}0.00(0.00 \\
\text { to } 0.32)\end{array}$ & $\begin{array}{r}0.08(0.01 \\
\text { to } 1.20)\end{array}$ & $\begin{array}{l}0.37(0.14 \text { to } \\
0.94)\end{array}$ \\
\hline & & & & & & & Liquorice & $\begin{array}{r}>100(0.19 \\
\text { to }>100)\end{array}$ & $\begin{array}{c}>100(1.05 \text { to } \\
>100)\end{array}$ \\
\hline & & & & & & & & Magnesium & $\begin{array}{l}4.61(0.31 \text { to } \\
66.63)\end{array}$ \\
\hline & & & & & & & & & Corticosteroids \\
\hline
\end{tabular}

Quantities reported are $95 \%$ credible intervals of the final odds ratios combining direct/indirect estimates. Both point estimates and credible intervals are considered when ranking treatments.

TABLE 5 Hoarseness at $24 \mathrm{hr}$

\begin{tabular}{|c|c|c|c|c|c|c|c|c|c|}
\hline \multirow[t]{10}{*}{ Benzydamine } & $\begin{array}{l}8.74(1.35 \\
\quad \text { to } 84.42)\end{array}$ & $\begin{array}{l}1.59(0.09 \\
\text { to } 35.99)\end{array}$ & $\begin{array}{l}1.78(0.07 \\
\text { to } 65.85)\end{array}$ & $\begin{array}{l}2.12(0.16 \text { to } \\
33.83)\end{array}$ & $\begin{array}{c}8.73(0.87 \text { to } \\
125.42)\end{array}$ & $\begin{array}{l}2.51(0.31 \\
\quad \text { to } 32.73)\end{array}$ & $\begin{array}{l}6.07(0.86 \\
\quad \text { to } 68.74)\end{array}$ & $\begin{array}{l}0.00(0.00 \\
\text { to } \\
>100)\end{array}$ & $\begin{array}{l}2.95(0.41 \text { to } \\
31.29)\end{array}$ \\
\hline & $\begin{array}{l}\text { Intracuff } \\
\text { air }\end{array}$ & $\begin{array}{r}0.18(0.02 \\
\text { to } 1.52)\end{array}$ & $\begin{array}{r}0.20(0.01 \\
\text { to } 3.06)\end{array}$ & $\begin{array}{l}0.24(0.04 \text { to } \\
1.22)\end{array}$ & $\begin{array}{l}1.02(0.24 \text { to } \\
3.81)\end{array}$ & $\begin{array}{r}0.28(0.10 \\
\text { to } 0.80)\end{array}$ & $\begin{array}{l}0.70(0.32 \\
\text { to } 1.478)\end{array}$ & $\begin{array}{l}0.00(0.00 \\
\text { to }>100)\end{array}$ & $\begin{array}{l}0.34(0.16 \text { to } \\
0.66)\end{array}$ \\
\hline & & $\begin{array}{l}\text { Intracuff } \\
\text { lidocaine }\end{array}$ & $\begin{array}{r}1.11(0.22 \\
\text { to } 5.86)\end{array}$ & $\begin{array}{l}1.32(0.08 \text { to } \\
19.57)\end{array}$ & $\begin{array}{l}5.64(0.40 \text { to } \\
69.10)\end{array}$ & $\begin{array}{l}1.57(0.15 \\
\text { to } 17.15)\end{array}$ & $\begin{array}{l}3.84(0.38 \\
\quad \text { to } 38.92)\end{array}$ & $\begin{array}{l}0.00(0.00 \\
\quad \text { to }>100)\end{array}$ & $\begin{array}{l}1.88(0.19 \text { to } \\
18.30)\end{array}$ \\
\hline & & & $\begin{array}{c}\text { Intracuff } \\
0.9 \% \\
\text { saline }\end{array}$ & $\begin{array}{l}1.20(0.04 \text { to } \\
27.43)\end{array}$ & $\begin{array}{c}5.10(0.23 \text { to } \\
102.78)\end{array}$ & $\begin{array}{r}1.44(0.08 \\
\text { to } 6.16)\end{array}$ & $\begin{array}{l}3.52(0.20 \\
\text { to } 59.46)\end{array}$ & $\begin{array}{l}0.00(0.00 \\
\quad \text { to }>100)\end{array}$ & $\begin{array}{l}1.72(0.09 \text { to } \\
26.82)\end{array}$ \\
\hline & & & & $\begin{array}{l}\text { Inhaled } \\
\quad \text { corticosteroids }\end{array}$ & $\begin{array}{l}4.31(0.51 \text { to } \\
41.03)\end{array}$ & $\begin{array}{l}1.19(0.17 \\
\text { to } 10.06)\end{array}$ & $\begin{array}{l}2.96(0.48 \\
\quad \text { to } 21.31)\end{array}$ & $\begin{array}{l}0.00(0.00 \\
\quad \text { to }>100)\end{array}$ & $\begin{array}{l}1.41(0.23 \text { to } \\
9.72)\end{array}$ \\
\hline & & & & & $\begin{array}{c}\text { Water-based } \\
\text { lubricant }\end{array}$ & $\begin{array}{r}0.28(0.05 \\
\text { to } 1.58)\end{array}$ & $\begin{array}{r}0.69(0.19 \\
\text { to } 2.63)\end{array}$ & $\begin{array}{l}0.00(0.00 \\
\text { to }>100)\end{array}$ & $\begin{array}{l}0.33(0.10 \text { to } \\
1.18)\end{array}$ \\
\hline & & & & & & Ketamine & $\begin{array}{r}2.47(0.69 \\
\text { to } 8.71)\end{array}$ & $\begin{array}{l}0.00(0.00 \\
\text { to }>100)\end{array}$ & $\begin{array}{l}1.19(0.34 \text { to } \\
3.79)\end{array}$ \\
\hline & & & & & & & Lidocaine & $\begin{array}{l}0.00(0.00 \\
\text { to }>100)\end{array}$ & $\begin{array}{l}0.48(0.21 \text { to } \\
1.06)\end{array}$ \\
\hline & & & & & & & & Magnesium & $\begin{array}{l}>100(0.00 \text { to } \\
>100)\end{array}$ \\
\hline & & & & & & & & & Corticosteroid \\
\hline
\end{tabular}

Quantities reported are 95\% credible intervals of the final odds ratios combining direct/indirect estimates. Because of few or zero events in one of the comparative groups, the relative odds ratio for some variables are extremely large, these resulting odds ratio values have been represented as values $>100$ in the above table. Both point estimates and credible intervals are considered when ranking treatments.

coefficients (e.g., the OR exp [ $\beta]$ ). Posterior means and $95 \% \mathrm{CrI}$ can be used to summarize these posteriors. ${ }^{92}$

We found that covariates of interest did not have uniform distribution across all the treatment groups. This was because there were fewer comparisons of liquorice, water-based lubricant and inhaled corticosteroids than of lidocaine, ketamine, and benzydamine. This is likely to have an impact on the ability to accurately estimate 
TABLE 6 Summary of findings for all topical agents compared with control for different outcomes (based on GRADEPro)

\begin{tabular}{|c|c|c|c|c|c|c|}
\hline \multirow{2}{*}{ Outcomes } & \multicolumn{2}{|c|}{$\begin{array}{l}\text { Anticipated absolute } \\
\text { effects }{ }^{*}(95 \% \mathrm{CrI})\end{array}$} & \multirow{2}{*}{$\begin{array}{c}\text { Relative } \\
\text { effect } \\
(95 \% \mathrm{CrI})\end{array}$} & \multirow{2}{*}{$\begin{array}{l}\text { № of } \\
\text { participants } \\
\text { (studies) }\end{array}$} & \multirow{2}{*}{$\begin{array}{c}\text { Certainty } \\
\text { of the } \\
\text { evidence } \\
\text { (GRADE) }\end{array}$} & \multirow[b]{2}{*}{ Comments } \\
\hline & $\begin{array}{l}\text { Risk with } \\
\text { control }\end{array}$ & $\begin{array}{l}\text { Risk with } \\
\text { topical } \\
\text { agents }\end{array}$ & & & & \\
\hline $\begin{array}{l}\text { Postoperative sore } \\
\text { throat at } 24 \mathrm{hr}\end{array}$ & $\begin{array}{c}390 \text { per } \\
1,000 \\
(360.2 \text { to } \\
420.6)\end{array}$ & $\begin{array}{c}201 \text { per } \\
1,000 \\
(177.3 \text { to } \\
227.0)\end{array}$ & $\begin{array}{c}0.52 \\
(0.45 \text { to } 0.60)\end{array}$ & $\begin{array}{c}7,141 \\
\text { (70 RCTs) }\end{array}$ & $\begin{array}{l}\oplus \oplus \bigcirc \bigcirc \\
\text { LOW't }\end{array}$ & $\begin{array}{l}\text { For combined direct and } \\
\text { indirect evidence, magnesium } \\
\text { (OR, 0.10; } 95 \% \text { CrI, } 0.03 \text { to } \\
0.26) \text { followed by steroid (OR, } \\
0.11 ; 95 \% \text { CrI, } 0.06 \text { to } 0.22) \\
\text { and liquorice are the best } \\
\text { prophylactic agents. }\end{array}$ \\
\hline $\begin{array}{l}\text { Postoperative sore } \\
\text { throat at } 4-6 \mathrm{hr}\end{array}$ & $\begin{array}{c}444 \text { per } \\
1,000 \\
(413.5 \text { to } \\
475.0)\end{array}$ & $\begin{array}{c}261 \text { per } \\
1,000 \\
(234.7 \text { to } \\
289.1)\end{array}$ & $\begin{array}{c}0.59 \\
(0.52 \text { to } 0.67)\end{array}$ & $\begin{array}{c}4,813 \\
(42 \text { RCTs) }\end{array}$ & $\begin{array}{l}\oplus \oplus \bigcirc \bigcirc \\
\text { LOW\# }\end{array}$ & $\begin{array}{l}\text { For combined direct and } \\
\text { indirect evidence, inhaled } \\
\text { corticosteroids (OR, } 0.03 \text {; } \\
95 \% \text { CrI, } 0.00 \text { to } 0.33) \\
\text { followed by benzydamine } \\
(\mathrm{OR}, 5.00 ; 95 \% \text { CrI. } 2.38 \text { to } \\
10.53) \text { and ketamine are the } \\
\text { best prophylactic agents. }\end{array}$ \\
\hline Cough at $24 \mathrm{hr}$ & $\begin{array}{c}284 \text { per } \\
1,000 \\
(256.9 \text { to } \\
312.7)\end{array}$ & $\begin{array}{c}130 \text { per } \\
1,000 \\
(110.6 \text { to } \\
152.3)\end{array}$ & $\begin{array}{c}0.46 \\
(0.38 \text { to } 0.55)\end{array}$ & $\begin{array}{c}2,405 \\
(23 \text { RCTs) }\end{array}$ & $\begin{array}{l}\oplus \oplus \bigcirc \bigcirc \\
\text { LOW't: }\end{array}$ & $\begin{array}{l}\text { For combined direct and } \\
\text { indirect evidence, } \\
\text { benzydamine }(\mathrm{OR},>100 ; \\
95 \% \mathrm{CrI}, 8.01 \text { to }>100) \\
\text { followed by liquorice }(\mathrm{OR}, \\
0.00 ; 95 \% \text { CrI, } 0.00 \text { to } 0.28) \\
\text { and magnesium are the best } \\
\text { prophylactic agents. }\end{array}$ \\
\hline Hoarseness at $24 \mathrm{hr}$ & $\begin{array}{c}281 \text { per } \\
1,000 \\
(254.0 \text { to } \\
309.7)\end{array}$ & $\begin{array}{c}184 \text { per } \\
1,000 \\
(161.2 \text { to } \\
209.2)\end{array}$ & $\begin{array}{c}0.65 \\
(0.56 \text { to } 0.77)\end{array}$ & $\begin{array}{c}2,600 \\
(24 \text { RCTs) }\end{array}$ & $\begin{array}{l}\oplus \oplus \bigcirc \bigcirc \\
\text { LOW }+\$\end{array}$ & $\begin{array}{l}\text { For combined direct and } \\
\text { indirect evidence, magnesium } \\
(\mathrm{OR}, 0.00 ; 95 \% \text { CrI, } 0.00 \text { to }> \\
100) \text { followed by } \\
\text { benzydamine (OR, } 8.74 ; 95 \% \\
\text { CrI, } 1.35 \text { to } 84.42) \text { and } \\
\text { intracuff lidocaine are the } \\
\text { best prophylactic agents. }\end{array}$ \\
\hline
\end{tabular}

* The risk in the intervention group (and its $95 \% \mathrm{CrI}$ ) is based on the assumed risk in the comparison group and the relative effect of the intervention (and its $95 \% \mathrm{CrI}$ )

$\dagger$ Inconsistency; $\ddagger$ Imprecision; $\ddagger$ Indirectness. $\mathrm{CrI}=$ credible interval; $\mathrm{OR}=$ odds ratio; $\mathrm{RCT}=$ randomized-controlled trial; relative effect presented as odds ratios with $\mathrm{CrI}$

GRADE working group of evidence

High certainty: We are very confident that the true effect lies close to that of the estimate of the effect

Moderate certainty: We are moderately confident in the effect estimate: the true effect is likely to be close to the estimate of the effect, but there is a possibility that it is substantially different

Low certainty: Our confidence in the effect estimate is limited: the true effect may be substantially different from the estimate of the effect Very low certainty: We have very little confidence in the effect estimate: the true effect is likely to be substantially different from the estimate of effect 
contribution of covariates to the observed outcomes. Further, given the number of interventions available with huge variations, we had to group various topical medication routes together for comprehensibility. We acknowledge that there is a possibility that variations in drug delivery methods within topical groups could have affected the outcome, but there was no feasible way of performing a separate subgroup analysis given the small number of patients in each subgroup. We also planned to perform meta-regression for nature and duration of surgery. Nevertheless because of marked variations among these variables, a valid subgrouping was not deemed appropriate.

Given that it is difficult to separate the top three agents in this regard, other factors such as local availability and ease of administration may determine the most appropriate choice in different settings. Estimation of appropriate doses was not possible because of varying doses used in enrolled trials. Similarly, in absence of reporting of adverse effect in various studies, we could not conclude which drug was associated with least adverse effects.

In conclusion, topical magnesium showed the greatest probability of reducing postoperative sore throat at $24 \mathrm{hr}$ (low quality of evidence) following surgery. This was followed by liquorice and corticosteroid (low quality of evidence) application. Intracuff air and topical lidocaine were associated with the lowest probability of a good outcome. Inhaled corticosteroids were found to be the most effective modality in decreasing early (4-6 hr) sore throat. Benzydamine and liquorice ranked as top agents for prevention of cough at $24 \mathrm{hr}$ while magnesium and benzydamine scored highly for prevention of hoarseness at $24 \mathrm{hr}$. More evidence is needed to formulate stronger recommendations in favour of efficacy of magnesium to prevent sore throat.

\begin{abstract}
Author contributions Narinder P. Singh and Jeetinder K. Makkar contributed to study conception, data collection, manuscript drafting, and revisions. Ron B. Cappellani, Ashish Sinha, and Anand Lakshminarasimhachar contributed to manuscript drafting and revision. Preet Mohinder Singh contributed to study conception, statistical analysis, manuscript drafting, and revision.
\end{abstract}

Disclosure None.

Funding statement None.

Editorial responsibility This submission was handled by Dr. Gregory L. Bryson, Deputy Editor-in-Chief, Canadian Journal of Anesthesia.

\section{References}

1. Macario A, Weinger M, Carney S, Kim A. Which clinical anesthesia outcomes are important to avoid? The perspective of patients. Anesth Analg 1999; 89: 652-8.

2. McHardy FE, Chung F. Postoperative sore throat: cause, prevention and treatment. Anaesthesia 1999; 54: 444-53.

3. Higgins PP, Chung F, Mezei G. Postoperative sore throat after ambulatory surgery. Br J Anaesth 2002; 88: 582-4.

4. El-Boghdadly $K$, Bailey $C R$, Wiles $M D$. Postoperative sore throat: a systematic review. Anaesthesia 2016; 71: 706-17.

5. Park SY, Kim SH, Lee SJ, et al. Application of triamcinolone acetonide paste to the endotracheal tube reduces postoperative sore throat: a randomized controlled trial. Can J Anesth 2011; 58: 436-42.

6. Flexman AM, Duggan $L V$. Postoperative sore throat: inevitable side effect or preventable nuisance? Can J Anesth 2019; 66: 1009-13.

7. Chandler $M$. Tracheal intubation and sore throat: a mechanical explanation. Anaesthesia 2002; 57: 155-61.

8. Kuriyama A, Maeda $H$, Sun R, Aga M. Topical application of corticosteroids to tracheal tubes to prevent postoperative sore throat in adults undergoing tracheal intubation: a systematic review and meta-analysis. Anaesthesia 2018; 73: 1546-56.

9. Kuriyama A, Aga M, Maeda $H$. Topical benzydamine hydrochloride for prevention of postoperative sore throat in adults undergoing tracheal intubation for elective surgery: a systematic review and meta-analysis. Anaesthesia 2018; 73: 889900.

10. Tanaka $Y$, Nakayama $T$, Nishimori $M$, et al. Lidocaine for preventing postoperative sore throat. Cochrane Database Sys Rev 2015; . https://doi.org/10.1002/14651858.CD004081.pub3.

11. Mayhood J, Cress K. Effectiveness of ketamine gargle in reducing postoperative sore throat in patients undergoing airway instrumentation: a systematic review. JBI Database System Rev Implement Rep 2015; 13: 244-78.

12. Hutton B, Salanti G, Caldwell DM, et al. The PRISMA extension statement for reporting of systematic reviews incorporating network meta-analyses of health care interventions: checklist and explanations. Ann Intern Med 2015; 162: 777-84.

13. Puhan MA, Schünemann HJ, Murad MH, et al. GRADE Working Group. A GRADE Working Group approach for rating the quality of treatment effect estimates from network meta-analysis. BMJ 2014; https://doi.org/10.1136/bmj.g5630.

14. Tonin FS, Rotta I, Mendes AM, Pontarolo R. Network metaanalysis: a technique to gather evidence from direct and indirect comparisons. Pharm Pract 2017; . https://doi.org/10.18549/ PharmPract.2017.01.943.

15. Sterne JA, Savović J, Page MJ, et al. RoB 2: a revised tool for assessing risk of bias in randomised trials. BMJ 2019; . https:// doi.org/10.1136/bmj.14898.

16. Sumathi PA, Shenoy T, Ambareesha M, Krishna HM. Controlled comparison between betamethasone gel and lidocaine jelly applied over tracheal tube to reduce postoperative sore throat, cough, and hoarseness of voice. Br J Anaesth 2008; 100: 215-8.

17. Agarwal A, Nath SS, Goswami D, et al. An evaluation of the efficacy of aspirin and benzydamine hydrochloride gargle for attenuating postoperative sore throat: a prospective, randomized, single-blind study. Anesth Analg 2006; 103: 1001-3.

18. Canbay $O$, Celebi $N$, Sahin A, et al. Ketamine gargle for attenuating postoperative sore throat. Br J Anaesth 2008; 100: 490-3.

19. Borazan H, Kececioglu A, Okesli S, Otelcioglu S. Oral magnesium lozenge reduces postoperative sore throat: a 
randomized, prospective, placebo-controlled study. Anesthesiology 2012; 117: 512-8.

20. Souissi H, Fréchette Y, Murza A, et al. Intracuff $160 \mathrm{mg}$ alkalinized lidocaine reduces cough upon emergence from $\mathrm{N}_{2} \mathrm{O}-$ free general anesthesia: a randomized controlled trial. Can $\mathbf{J}$ Anesth 2016; 63: 862-70.

21. Thomas D, Bejoy R, Zabrin N, Beevi S. Preoperative ketamine nebulization attenuates the incidence and severity of postoperative sore throat: a randomized controlled clinical trial. Saudi J Anaesth 2018; 12: 440-5.

22. Rajan S, Tosh P, Paul J, Kumar L. Effect of inhaled budesonide suspension, administered using a metered dose inhaler, on postoperative sore throat, hoarseness of voice and cough. Indian $\mathbf{J}$ Anaesth 2018; 62: 66-71.

23. Charan S, Khilji Mohd Y, Jain R, Devra V, Saxena M. Inhalation of ketamine in different doses to decrease the severity of postoperative sore throat in surgeries under general anesthesia patients. Anesth Essays Res 2018; 12: 625-9.

24. Budania LS, Chamala V, Rao M, et al. Effect of air, anesthetic gas mixture, saline, or $2 \%$ lignocaine used for tracheal tube cuff inflation on coughing and laryngotracheal morbidity after tracheal extubation. J Anaesthesiol Clin Pharmacol 2018; 34(6): 386-91.

25. Thapa $P$, Shrestha RR, Shrestha S, Bajracharya GR. Betamethasone gel compared with lidocaine jelly to reduce tracheal tube related postoperative airway symptoms: a randomized controlled trial. BMC Res Notes 2017; . https://doi. org/10.1186/s13104-017-2694-6.

26. Rajan S, Malayil G, Varghese R, Kumar L. Comparison of usefulness of ketamine and magnesium sulfate nebulizations for attenuating postoperative sore throat, hoarseness of voice, and cough. Anesth Essays Res 2017; 11: 287-93.

27. Jain S, Barasker $S K$. A comparative study of preoperative ketamine and $\mathrm{MgSO} 4$ nebulisation for incidence of post operative sore throat after endotracheal intubation. Int J Contemp Med Res 2017; 4: 1356-9.

28. Sharma M, Gupta S, Purohit S, Goyal AK. The effect of intravenous dexamethasone on intraoperative and early postoperative pain in lumbar spine surgery: a randomized double-blind placebo-controlled study. Anesth Essays Res 2018; 12: 803-8

29. Varghese Thoppil J, Rani Imanual S. Efficacy of ketamine gargle for attenuating postoperative sore throat in patients undergoing general anaesthesia with endotracheal intubation. J Evolution Med Dent Sci 2017; 6: 5707-11.

30. Aditya AK, Das B, Mishra DK. Assessment of nebulized ketamine for reductions of incidence and severity of post-operative sore throat. Int J Med Health Res 2017; 3: 130-2.

31. Lalwani J, Thakur R, Tandon M, Bhagat $S$. To study the effect of ketamine gargle for attenuating post operative sore throat, cough and hoarseness of voice. J Anest Inten Care Med 2017; . https:// doi.org/10.19080/JAICM.2017.04.555642.

32. Takhelmatum SH, Longjam DE, Mithun $R$, et al. Effect of intracuff plain lignocaine and alkalinized lignocaine for prevention of postoperative sore throat. IJHRMLP 2017; 3: 64-8.

33. Fayyaz A, Furqan A, Ammar A, Akhtar $R$. Comparing the effectiveness of betamethasone gel with lidocaine gel local application on tracheal tube in preventing post-operative sore throat (POST). J Pak Med Assoc 2017; 67: 873-6.

34. Mafiana R, Maas EM, Theodorus, Wijaya W. Comparison of the efficacy between triamcinolone gel $0,1 \%$ and lidocaine gel $2 \%$ applied over tracheal tube to reduce postoperative sore throat, cough, and hoarseness after general anesthesia. Int J Health Sci Res 2017; 7: 6-15.

35. Firza TA, Umar $N$, Ihsan $M$. Comparison of benzydamine hydrochloride $22.5 \mathrm{mg}$ and ketamine $40 \mathrm{mg}$ mouthwash reduce sore throat and hoarseness after endotracheal intubation. Jurnal Anestesi Perioperatif 2017; 5: 57-66.

36. Lee J, Lee YC, Son J-D, Lee JY, Kim HC. The effect of lidocaine jelly on a taper-shaped cuff of an endotracheal tube on the postoperative sore throat: a prospective randomized study. Medicine (Baltimore) 2017; . https://doi.org/10.1097/MD. 0000000000008094.

37. Gaur $P$, Ubale $P$, Khadanga $P$. Efficacy and safety of using air versus alkalinized $2 \%$ lignocaine for inflating endotracheal tube cuff and its pressure effects on incidence of postoperative coughing and sore throat. Anesth Essays Res 2017; 11: 1057-63.

38. Mehrotra S, Kumar N, Khurana G, Bist SS. Post operative sore throat: incidence after nebulization with ketamine, lidocaine and budesonide. Int J Medical Science Clin Invention 2017; 4: 29948.

39. Narimani M, Mehdi SA, Gholami $F$, et al. The effect of betamethasone gel and lidocaine jelly applied over tracheal tube cuff on postoperative sore throat, cough, and hoarseness. J Perianesth Nurs 2016; 31: 298-302.

40. Mekhemar NA, El-Agwany AS, Radi WK, El-Hady SM. Comparative study between benzydamine hydrochloride gel, lidocaine $5 \%$ gel and lidocaine $10 \%$ spray on endotracheal tube cuff as regards postoperative sore throat. Braz J Anesthesiol 2016; 66: 242-8.

41. Chari VR, Paul A. Comparative study to analyze the incidence of sore throat, cough, and hoarseness of voice after general anesthesia with the use of topical benzydamine hydrochloride and 2\% lignocaine gel with placebo. Med J DY Patil Univ 2016; 9: 61-5.

42. Gaikwad S, Rupwate K, Tendolkar B. A prospective, randomized, double blind, placebo controlled clinical trial to study efficacy and safety of benzydamine $0.15 \%$ gargles in prevention of postoperative sore throat. Int J Res Med Sci 2016; 4: 2420-7.

43. Yadav M, Chalumuru N, Gopinath R. Effect of magnesium sulfate nebulization on the incidence of postoperative sore throat. $\mathrm{J}$ Anaesthiol Clin Pharmacol 2016; 32: 168-71.

44. Chattopadhyay S, Das A, Nandy S, et al. Postoperative sore throat prevention in ambulatory surgery: a comparison between preoperative aspirin and magnesium sulfate gargle - a prospective, randomized, double-blind study. Anesth Essays Res 2017; 11: 94-100.

45. Zheng $Y, W u M$, Bai $Y$. Effect of betamethasone gel on postoperative sore throat, cough and hoarseness after tracheal intubation. China Medicine 2016; 11: 1852-4.

46. Sarki AM, Mohammed AD. A comparison of betamethasone gel and lidocaine jelly as prophylaxis against intubation-associated throat complications. Niger J Basic Clin Sci 2015; 12: 105-10.

47. Handady SO, Elsir Y, Sanhouri M, Mimoun H, Alawad AA. The effect of betamethasone gel in reducing post operative sore throat and cough after tracheal intubation in Khartoum teaching hospital in Sudan. Open Sci J Clin Med 2015; 3: 140-4.

48. Muhammad M, Fuadi I, Mawawi AM. Effectiveness of benzydamine $\mathrm{HCl} 0.15 \%$ spray and lidocaine $2 \%$ gel on postoperative sore throat incidence. Jurnal Anestesi Perioperatif 2015; 3: 123-30.

49. Ahuja V, Mitra S, Sarna $R$. Nebulized ketamine decreases incidence and severity of post-operative sore throat. Indian $\mathrm{J}$ Anaesth 2015; 59: 37-42.

50. Kamble NP, Gajbhare NK. Efficacy of ketamine gargles in the prevalence of postoperative sore throat after endotracheal intubation. Indian J Clin Anaesth 2015; 2: 251-5.

51. Sharma RP, Vaidya PR, Chand MB. The efficacy of ketamine gargle in attenuating postoperative sore throat: a randomized control trial. J Lumbini Med Coll 2015; 3: 8-11.

52. Salman W, Shamim A, Shounthoo RS, Gul DS. A comparative study between intracuff alkalinized lignocaine, intracuff plain 
lignocaine and intracuff air for decreasing post intubation sore throat and emergence phenomena. IOSR J Dental Med Sci 2015; 14: 60-6.

53. Banihashem N, Alijanpour E, Hasannasab B, Zarei A. Prophylactic effects of lidocaine or beclomethasone spray on post-operative sore throat and cough after orotracheal intubation. Iranian J Otorhinolaryngol 2015; 27: 179-84.

54. Teymourian H, Mohajerani SA, Farahbod A. Magnesium and ketamine gargle and postoperative sore throat. Anesth Pain Med 2015; . https://doi.org/10.5812/aapm.5(3)2015.22367.

55. Safavi M, Honarmand A, Fariborzifar A, Attari M. Intravenous dexamethasone versus ketamine gargle versus intravenous dexamethasone combined with ketamine gargle for evaluation of post-operative sore throat and hoarseness: a randomized, placebo-controlled, double blind clinical trial. Adv Biomed Res 2014; . https://doi.org/10.4103/2277-9175.143257.

56. Tabari $M$, Soltani $G$, Zirak $N$, Alipour $M$, Khazaeni $K$. Comparison of effectiveness of betamethasone gel applied to the tracheal tube and IV dexamethasone on postoperative sore throat: a randomized controlled trial. Iran $\mathrm{J}$ Otorhinolaryngol 2013; 25: 215-20.

57. Akram A, Ali L, Aslam M, Ali SK. Comparison of frequency of postoperative sore throat, cough and hoarseness of voice with and without betamethasone gel application on tracheal tube. Pakistan J Med and Health Sci 2013; 7: 820-3.

58. Nimmaanrat $S$, Chokkijchai $K$, Chanchayanon $T$. Efficacy of benzydamine hydrochloride dripping at endotracheal tube cuff for prevention of postoperative sore throat. J Med Assoc Thailand 2013; 96: 1331-7.

59. D'Aragon F, Beaudet $N$, Gagnon V, Martin R, Sansoucy $Y$. The effects of lidocaine spray and intracuff alkalinized lidocaine on the occurrence of cough at extubation: a double-blind randomized controlled trial. Can J Anesth 2013; 60: 370-6.

60. Ghaleb MA, Falatah S, Al-Amoudi FA. The efficacy of licorice gargle for attenuating postoperative sore throat. American J Res Communication. 2013; 1: 379-94.

61. Gupta D, Agrawal S, Sharma JP. Effect of preoperative licorice lozenges on incidence of postextubation cough and sore throat in smokers undergoing general anesthesia and endotracheal intubation. Middle East J Anaesthesiol 2013; 22: 173-8.

62. Shaaban AR, Kamal SM. Comparison between betamethasone gel applied over tracheal tube and ketamine gargle for attenuating postoperative sore throat, cough and hoarseness of voice. Middle East J Anaesthesiol 2012; 21: 513-9.

63. Rajkumar G, Eshwori L, Konyak PY, et al. Prophylactic ketamine gargle to reduce post-operative sore throat following endotracheal intubation. J Med Soc 2012; 26: 175-9.

64. Navarro LH, Lima RM, Aguiar AS, et al. The effect of intracuff alkalinized $2 \%$ lidocaine on emergence coughing, sore throat, and hoarseness in smokers. Rev Assoc Med Bras 2012; 58: 248-53.

65. Guo H-M, Pang Z-l, Sun Z, Li P-H, Han X-P. The clinical research of compound dexamethasone gel applied over tracheal tube to prevent postoperative airway complications. Henan Med Res 2012; 21: 60-2.

66. Doukumo D, Faponle A, Adenekan A, Olateju S, Bolaji B. Effects of lidocaine and $\mathrm{K}-\mathrm{Y}$ jellies on sore throat, cough, and hoarseness following endotracheal anaesthesia. J West Afr Coll Surg 2011; 1: 44-61.

67. Narasethakamol A, Techanivate A, Saothongthong J, Yurakate N, Cousnit $P$. Application of mometasone spray to reduce sore throat after tracheal intubation. J Med Assoc Thailand 2011; 94: 958-64.

68. Hung NK, Wu CT, Chan SM, et al. Effect on postoperative sore throat of spraying the endotracheal tube cuff with benzydamine hydrochloride, 10\% lidocaine, and 2\% lidocaine. Anesth Analg 2010; 111: 882-6.
69. Huang YS, Hung NK, Lee MS, et al. The effectiveness of benzydamine hydrochloride spraying on the endotracheal tube cuff or oral mucosa for postoperative sore throat. Anesth Analg 2010; 111: 887-91.

70. Shrestha SK, Bhattarai B, Singh J. Ketamine gargling and postoperative sore throat. J Nepal Med Assoc 2010; 50: 282-5.

71. Tazeh-Kand NF, Eslami B, Mohammadian K. Inhaled fluticasone propionate reduces postoperative sore throat, cough, and hoarseness. Anesth Analg 2010; 111: 895-8.

72. Rudra A, Ray S, Chatterjee S, Ahmed A, Ghosh S. Gargling with ketamine attenuates the postoperative sore throat. Indian $\mathbf{J}$ Anaesth 2009; 53: 40-3.

73. Jaichandran V, Bhanulakshmi I, Jagadeesh V, Thennarasu M. Intracuff buffered lidocaine versus saline or air-A comparative study for smooth extubation in patients with hyperactive airways undergoing eye surgery. South African J Anaesth Analg 2009; 15: 11-4.

74. Sagheer AS, Iqbal M, Ali K. Effect of intracuff lignocaine on coughing during emergence and postoperative sore throat. Pakistan J Med and Health Sci 2009; 1: 50-4.

75. Agarwal A, Gupta D, Yadav G, et al. An evaluation of the efficacy of licorice gargle for attenuating postoperative sore throat: a prospective, randomized, single-blind study. Anesth Analg 2009; 109: 77-81.

76. Gulhas N, Canpolat H, Cicek M, et al. Dexpanthenol pastille and benzydamine hydrochloride spray for the prevention of postoperative sore throat. Acta Anaesth Scand 2007; 51: 239-43.

77. Navarro LHC, Braz JRC, Nakamura G, Lima RM e, Silva F de P $e$, Módolo NSP. Effectiveness and safety of endotracheal tube cuffs filled with air versus filled with alkalinized lidocaine: a randomized clinical trial. Sao Paulo Med J 2007; 125: 322-8.

78. Kazemi A, Amini A. The effect of betamethasone gel in reducing sore throat, cough, and hoarseness after laryngo-tracheal intubation. Middle East J Anaesthesiol 2007; 19: 197-204.

79. Basaranoglu G, Erden V, Delatioglu H. Postoperative sore throat: effect of lidocaine jelly and pomade on endotracheal intubation. J Clin Anesth 2004; 16: 79-80.

80. Soltani HA, Aghadavoudi $O$. The effect of different lidocaine application methods on postoperative cough and sore throat. J Clin Anesth 2002; 14: 15-8.

81. Selvaraj T, Dhanpal R. Evaluation of the application of topical steroids on the endotracheal tube in decreasing postoperative sore throat. J Anaesthesiol Clin Pharmacol 2002; 18: 167-70.

82. Altintaş F, Bozkurt P, Kaya G, Akkan G. Lidocaine $10 \%$ in the endotracheal tube cuff: blood concentrations, haemodynamic and clinical effects. Eur J Anaesthesiol 2000; 17: 436-42.

83. Ayoub MC, Ghobashy A, McGrimley L, Koch ME, Qadir S, Silverman $D G$. Wide spread application of topical steroids to decrease sore throat, hoarseness and cough after tracheal intubation. Anesth Analg 1998; 87: 714-6.

84. Navarro RM, Baughman VL. Lidocaine in the endotracheal tube cuff reduces postoperative sore throat. J Clin Anesth 1997; 9: 394-7.

85. Singh NP, Makkar JK, Wourms $V$, et al. Role of topical magnesium in post-operative sore throat: a systematic review and meta-analysis of randomised controlled trials. Indian $\mathrm{J}$ Anaesth 2019; 63: 520-9.

86. Kuriyama A, Maeda $H$, Sun R. Topical application of magnesium to prevent intubation-related sore throat in adult surgical patients: a systematic review and meta-analysis. Can J Anesth 2019; 66: 1082-94.

87. Parkes $A W$, Harper $N$, Herwadkar A, et al. Anaphylaxis to the chlorhexidine component of Instillagel: a case series. $\mathrm{Br} \mathrm{J}$ Anaesth 2009; 102: 65-8.

88. Schorr WF. Paraben allergy. A cause of intractable dermatitis. JAMA 1968; 204: 859-62. 
89. Hara K, Maruyama $K$. Effect of additives in lidocaine spray on postoperative sore throat, hoarseness and dysphagia after total intravenous anaesthesia. Acta Anaesthesiol Scand 2005; 49: 4637.

90. Liao AH, Yeoh SR, Lin YC, et al. Lidocaine lubricants for intubation-related complications: a systematic review and metaanalysis. Can J Anesth 2019; 66: 1221-39.

91. Tu HN, Saidi N, Leiutaud T, et al. Nitrous oxide increases endotracheal cuff pressure and the incidence of tracheal lesions in anesthetized patients. Anesth Analg. 1999; 89: 187-90.
92. Dunson DB. Commentary: practical advantages of Bayesian analysis of epidemiological data. Am J Epidemiol 2001; 153: $1222-6$.

Publisher's Note Springer Nature remains neutral with regard to jurisdictional claims in published maps and institutional affiliations. 